\title{
Genetic Predispositions of Glucocorticoid Resistance and Therapeutic Outcomes in Polymyalgia Rheumatica and Giant Cell Arteritis
}

\author{
Tomas Smutny ${ }^{1}$, Ivan Barvik ${ }^{2}$, Tomas Veleta ${ }^{3}$, Petr Pavek ${ }^{1}$ and Tomas Soukup ${ }^{4, *}$ \\ 1 Department of Pharmacology and Toxicology, Centre for Drug Development, Faculty of Pharmacy in Hradec \\ Kralove, Charles University, 50005 Hradec Kralove, Czech Republic; smutt6aa@faf.cuni.cz (T.S.); \\ pavek@faf.cuni.cz (P.P.) \\ 2 Institute of Physics, Faculty of Mathematics and Physics, Charles University, 12116 Prague, Czech Republic; \\ ibarvik@karlov.mff.cuni.cz \\ 3 Department of Emergency Medicine, University Hospital in Hradec Kralove, \\ 50005 Hradec Kralove, Czech Republic; tomas.veleta@fnhk.cz \\ 4 Division of Rheumatology, 2nd Department of Internal Medicine-Gastroenterology, Faculty of Medicine in \\ Hradec Kralove, Charles University and University Hospital in Hradec Kralove, \\ 50005 Hradec Kralove, Czech Republic \\ * Correspondence: soukutom@fnhk.cz; Tel.: +420-495834762
}

Received: 1 March 2019; Accepted: 25 April 2019; Published: 27 April 2019

\begin{abstract}
Polymyalgia rheumatica (PMR) and giant cell arteritis (GCA) are closely related chronic inflammatory diseases. Glucocorticoids (GCs) are first-choice drugs for PMR and GCA, although some patients show poor responsiveness to the initial GC regimen or experience flares after GC tapering. To date, no valid biomarkers have been found to predict which patients are at most risk for developing GC resistance. In this review, we summarize PMR- and GCA-related gene polymorphisms and we associate these gene variants with GC resistance and therapeutic outcomes. A limited number of GC resistance associated-polymorphisms have been published so far, mostly related to $H L A-D R B 1^{*} 04$ allele. Other genes such ICAM-1, TLR4 and 9,VEGF, and INFG may play a role, although discrepancies are often found among different populations. We conclude that more studies are required to identify reliable biomarkers of GC resistance. Such biomarkers could help distinguish non-responders from responders to GC treatment, with concomitant consequences for therapeutic strategy.
\end{abstract}

Keywords: pharmacogenetics; glucocorticoid resistance; giant cell arteritis; polymyalgia rheumatica

\section{Introduction}

Controversy remains as to whether polymyalgia rheumatica (PMR) and giant cell arteritis (GCA) are two different pathological conditions or manifestations of a single disease. They often overlap in the same patient and affect the same population. PMR is characterized by severe, usually bilateral pain involving the musculoskeletal structures of the neck, shoulder, and/or pelvic girdles, accompanied with morning stiffness. GCA (temporal arteritis) involves large- and medium-sized blood vessel systemic vasculitis manifested by the granulomatous inflammation of the aorta and its branches. The most serious symptom of GCA is visual loss caused by vasculitis-induced ischemia [1].

Based on previous observations, about $15 \%$ of PMR patients develop GCA [2]. Recently, positron emission tomography (PET) has opened new perspectives in diagnosis for GCA and may change ranges of PMR and GCA diagnoses. In accordance with PMR/GCA overlapping, using PET scans showed 
that a one-third of apparently isolated PMR patients suffer from inflammatory vessel involvement or clinically unrecognized GCA [3-5].

Both PMR and GCA only share common clinical characteristics such as an increase in acute phase reactants reflecting systemic inflammation as well as responsiveness to corticosteroids [6].

\subsection{Etiology and Pathogenesis}

The precise cause underlying PMR and GCA is unknown, although environmental, epigenetic and genetic factors appear to play a role in the development of pathological autoimmunity.

Cytokine-mediated gene regulation is implicated in the initiation of the inflammatory process in PMR and GCA.

In PMR, increased interstitial concentrations of pro-inflammatory cytokines have been found in affected muscles. Additionally, the inflammatory infiltrate was detected in synovial membranes predominantly in shoulders [7].

In GCA, cytokines increase the expression of endothelial cell adhesion molecules, leading to consecutive migration of leukocytes into tissue [8,9]. Subsequently, intimal hyperplasia and the fragmentation of internal elastic laminae lead to luminal narrowing. This is followed by ischemia (typically in nervus opticus), which results in visual symptoms [10].

Interestingly, ischemic complications have been associated with lower tissue expression of IL-6 and its circulating levels in GCA patients when compared with those GCA patients with no ischemic manifestations. A protective role of IL-6 can be explained by its direct effect on vascular wall components, resulting in a compensation for ischemia in GCA patients [11]. Blindness as a result of ischemic complications represents an important issue to be addressed by clinicians treating GCA patients. The identification of gene polymorphisms which may predict the risk of visual manifestations continues to be an issue of research interest.

Some shared immunologic abnormalities between PMR and GCA include the elevation of IL-6 and IL-10 along with a similar distribution of circulating CD4+ T cell subsets such as an increase in Th17 cells and decrease in Treg cells [12-14].

\subsection{Glucocorticoid Treatment of Polymyalgia Rheumatica and Giant Cell Arteritis}

Treatment with glucocorticoids (GCs) is the first-line therapy for both PMR and GCA. There are wide variations in the GC treatment of PMR and GCA with respect to dosages, tapering strategies, and the duration of treatment $[15,16]$. GC side effects are frequently observed, thus posing further challenges.

\subsection{Relapsing Diseases}

Approximately half of PMR patients experience a flare of disease activity upon GC tapering or discontinuation [17-19]. In a number of studies, increased levels of inflammatory parameters such as C-reactive protein (CRP) and erythrocyte sedimentation rate (ESR) at the beginning of the disease have been shown as risk factors for relapse/recurrence and thus longer GC therapy was required [20-24].

On the contrary, some published findings have described no clinical or laboratory parameters significantly associated with relapses or duration of GC therapy [25-27]. Recently, using a multivariate analysis, it was revealed that when patients were treated with an initial dose of $12.5 \mathrm{mg} /$ day prednisolone the only factor predicting good GC responders among PMR patients is lower weight (responders $67.4 \mathrm{~kg}$ vs. non-responders $78.5 \mathrm{~kg}$ ) [28].

Regarding GCA, Restuccia et al. [29] studied relapses in 157 patients in northern Italy. Fifty-seven patients (36.5\%) experienced $\geq 1$ flares, with 51 (46.4\%) of the 110 total flares (88 relapses and 22 recurrences) appearing during the first 2 years after diagnosis. Fever and severe inflammation shown by a temporal artery biopsy seem to predict the incidence of disease flares. 


\section{Glucocorticoid Resistance}

Some patients show poor or absent response to GC treatment, with GCs having to be administered in high doses in these subjects. GC-resistant patients were defined as those who responded poorly to the initial GC regimen, or those who responded to the initial regimen but experienced a flare upon GC tapering to the maintenance dose. In this case, a flare was defined as the exacerbation or reappearance of symptoms associated with the acute phase response [30].

The GC resistance has been associated with a number of serious complications, including metabolic diseases as well as an increased risk of cardiovascular diseases [31-34].

Various therapeutic approaches have been applied with the aim of overcoming GC resistance. Methotrexate added to GC treatment has been associated with lower relapse rate and lower cumulative GC dosage in both PMR and GCA. Other conventional disease modifying antirheumatic drugs and TNF- $\alpha$ inhibitors did not seem to have a GC-sparing effect as systematically reviewed elsewhere [35]. Recent clinical trials demonstrated benefit of adjunctive tocilizumab, inhibitor IL-6R-mediated signaling, in the treatment of GCA patients [36].

The molecular basis of GC resistance (see Table 1, Figure 1) is poorly understood in PMR and GCA patients, however it has been widely studied in other inflammatory conditions. Immune system abnormalities have a significant role in disease pathogenesis and are able to dictate, not only clinical features, but also treatment outcomes. GC resistance may occur as a result of prolonged exposure to inflammatory cytokines [37]. Elevated expression of pro-inflammatory cytokines such as IL-1 $\beta, \mathrm{TNF} \alpha$ and IL- 6 in temporal biopsies reflects the stronger systemic inflammatory reaction in GCA patients. Those patients with higher tissue TNF $\alpha$ production also had longer requirements for prednisone administration [38]. Several studies showed that persistently elevated levels of serum IL-6 during GC therapy were significantly associated with an increased risk of relapse and recurrence of PMR activity, as well as with a prolonged course featuring an increased need for prednisolone $[17,20]$.

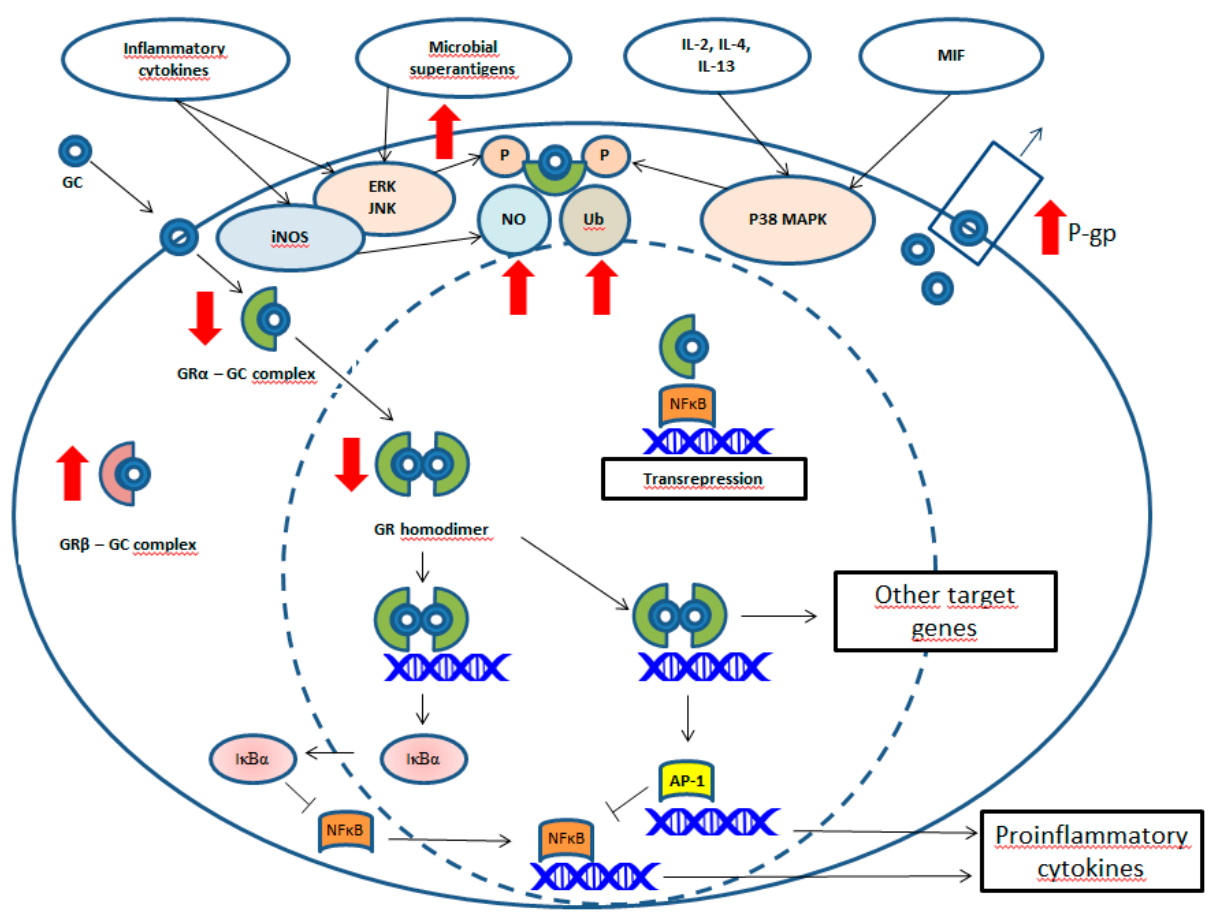

Figure 1. Molecular mechanisms of glucocorticoid (GC) action and GC resistance. GCs enter the target cell by passive transport through the cell membrane and they bind to the intracellular glucocorticoid receptor (GR)-alpha. GC binding to GR-beta is ineffective. Low GR-alpha: GR-beta ratio results in GC resistance. GC action is dependent on the GR-mediated transcriptional regulation of specific target genes (i.e., AP-1 gene). Their products in turn inhibit the promoter region of genes (i.e., gene encoding 
nuclear factor kappa B (NFkB)) which are potent transcription factors for many pro-inflammatory cytokines and adhesion molecules. Central to the anti-inflammatory action of GCs is the induction of inhibitor kappa B alpha $(\mathrm{I} \kappa \mathrm{B} \alpha)$, which inhibits NFкB by sequestering it in the cytoplasm. The decreased cytoplasmic GC concentration is a consequence of the overexpression of P-glycoprotein (P-gp), which leads to increased P-gp-mediated efflux of GCs. The following kinases can phosphorylate (P) GR: p38 mitogen-activated protein kinase (MAPK), which is activated by IL-2, IL-4, IL-13, or macrophage migration inhibitory factor (MIF); c-Jun N-terminal kinase (JNK); and extracellular signal-regulated kinases (ERK). Nitric oxide (NO) can nitrate tyrosine residues on GR. GR can also be ubiquitinated (Ub), which results in the degradation of GR by the proteasome. Red arrows indicate increase or decrease in GC resistance.

Glucocorticoid receptor (GR) is the target molecule for GC treatment. The success of GC therapy seems to reflect GR staining in the chronic inflammatory cells in GCA. Patients highly responding to GCs tend to have more GR-positive lymphocytes/monocytes comparing to those with incomplete treatment response. The number CD68-positive cells, a hallmark of the chronic inflammation, were also related to treatment success and GC resistance [39].

Table 1. Mechanisms of glucocorticoid resistance.

\begin{tabular}{l}
\hline Genetic Polymorphisms or Mutations of GR \\
\hline Chrousos syndrome-primary glucocorticoid resistance \\
Defective ligand binding to GR \\
Lower transport GR-GC complex to nucleus \\
Defective transactivation \\
Post-translational modifications of GR \\
\hline Phosphorylation \\
Nitrosylation \\
Ubiquitination \\
Increased GR $\beta$ expression \\
\hline Increased activity of pro-inflammatory transcription factors and kinases \\
\hline NFKB, AP1 \\
JNK, STAT5, JAK3 \\
Defective histone acetylation \\
\hline Reduced acetylation of lysine 5 on histone 4 \\
Reduced histone deacetylase 2 \\
Increased oxidative stress \\
\hline Increased phosphoinositide-3-kinase- $\delta$ activation \\
Increased P-glycoprotein \\
\hline Increased efflux of steroids \\
Inactivation of glucocorticoids \\
\hline Expression of $11 \beta$-hydroxysteroid dehydrogenase 2 \\
\hline
\end{tabular}

AP1, activator protein 1; JAK3, Janus kinase 3; JNK, c-Jun N-terminal kinase; NFKB, nuclear factor kappa B; STAT, signal transduction-activated transcription factor.

Braun et al. [39] aimed to determine the value of clinical genetic findings as well as the expression of GR for discriminating between GCA and PMR patients who achieve either complete remission or partial remission after GCs, as opposed to those who are resistant to GC treatment. A study on GC receptor polymorphisms revealed that more than $90 \%$ of patients had the wild-type genotype (homozygote) of R23K and N363S polymorphisms; no evidence was found that these polymorphisms influenced response to treatment with GCs. In our literature search, we found no other studies dealing with GC resistance and GR-related polymorphisms in the treatment of PMR and GCA. 


\section{Methods}

The systematic search for genetic associations to GCA and PMR was performed using DisGeNET database. DisGeNET version 5.1 (released in May, 2018) contains a compilation of genes associated to diseases integrating several widely used gene-disease databases [40]. Search results (54 for PMR and 240 for GCA) were further verified in full text papers available on PubMed. Duplicated findings and incorrectly categorized articles (as those including GCA for gastric cardia adenocarcinoma instead of giant cell arteritis) were excluded. Evidence relevant to the effect of GC treatment and ischemic complications (the prognostic factor for a worse GC treatment response) were included in review.

Additionally, two reviewers independently searched PubMed database for relevant publications without restriction of article type using "polymyalgia rheumatica" or "giant cell arteritis" as key words.

\section{Genetic Studies of GCA and PMR with Relevance of GC Treatment Outcome}

We performed an overview of genetic predisposition to GC treatment outcomes in GCA (Table 2) and PMR (Table 3) as a basis for further genetic studies, as well as for further consideration of new therapeutic strategies. The genes included in the review play a role in the pathogenesis of GCA and PMR, and they may also be involved in GC resistance and thus in disease severity.

Reports included in this manuscript encompass different approaches to defining GC resistance from a clinical point of view. The phenomenon of GC resistance in PMR and GCA is generally manifested by the absence of an expected response to a recommended GC dosage. GC resistance has been defined as experience of relapse/recurrence and/or higher and prolonged GC requirements in PMR patients. The persistence of various ischemic manifestations following GC treatment was considered as a marker of GC resistance in GCA patients. Since no universal definition of GC resistance could be obtained, we stated details on GC resistance for each study into Tables 2 and 3.

Table 2. Genetic susceptibility to glucocorticoid treatment outcomes in giant cell arteritis.

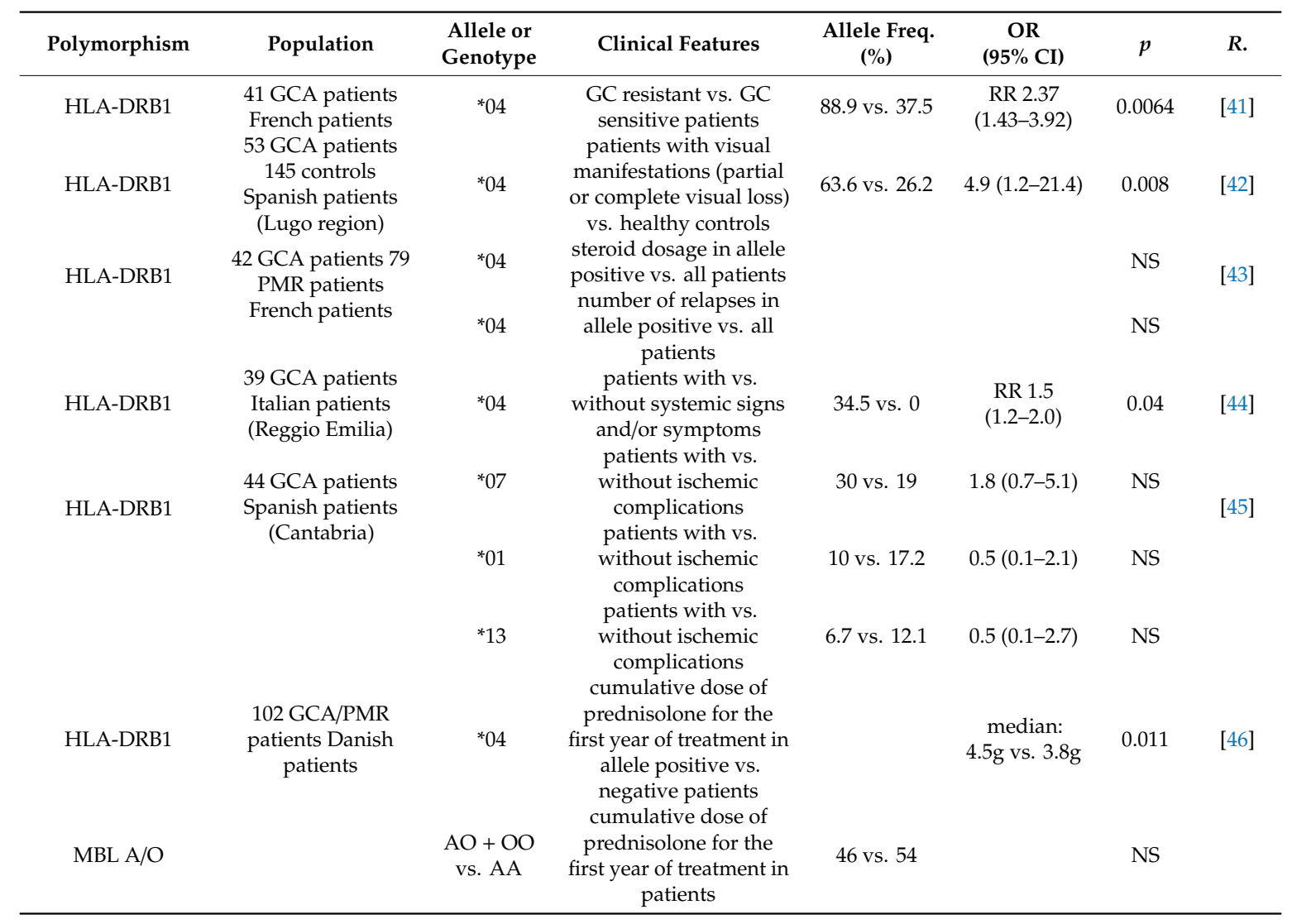


Table 2. Cont.

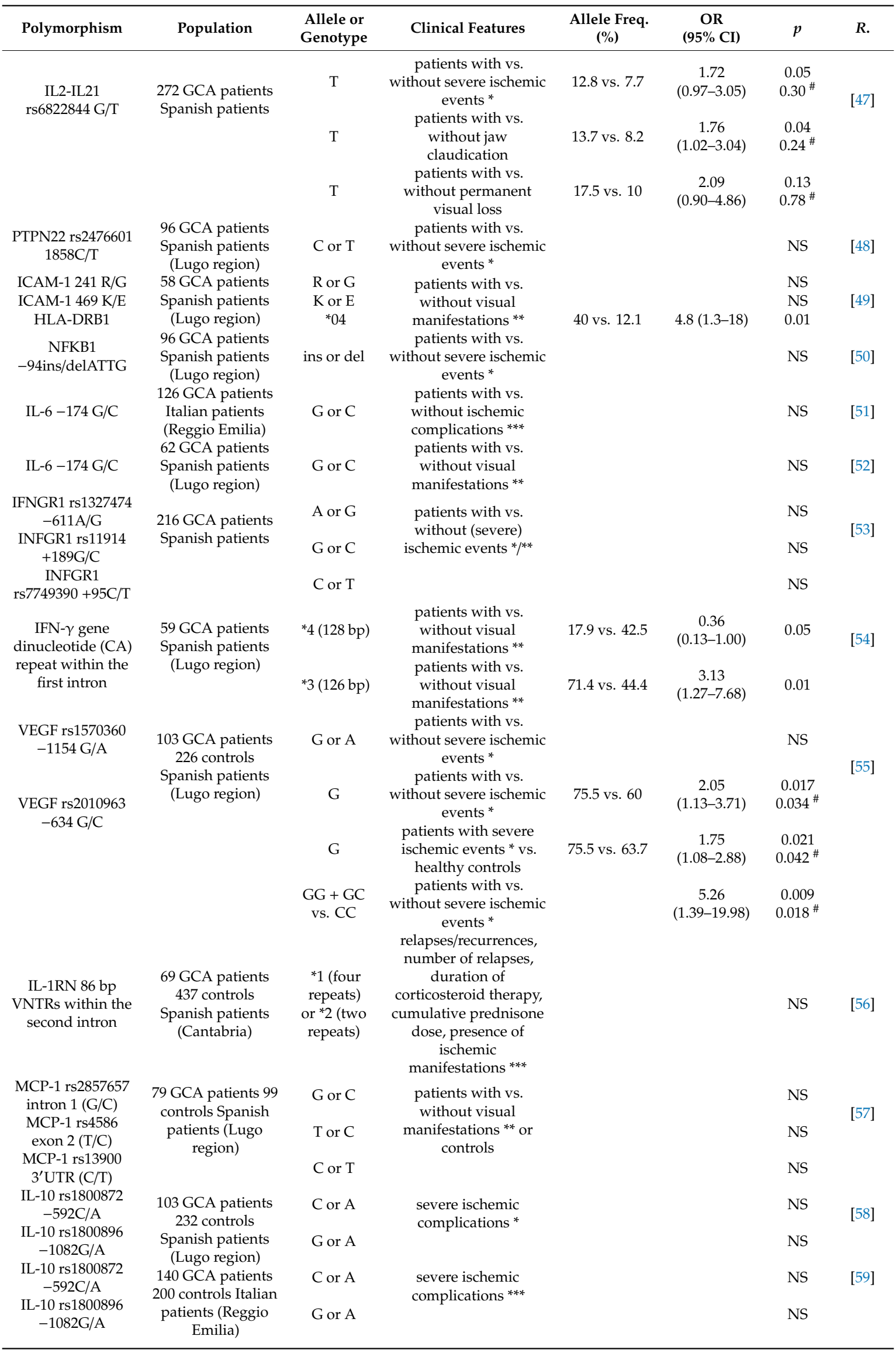


Table 2. Cont.

\begin{tabular}{|c|c|c|c|c|c|c|c|}
\hline Polymorphism & Population & $\begin{array}{l}\text { Allele or } \\
\text { Genotype }\end{array}$ & Clinical Features & $\begin{array}{l}\text { Allele Freq. } \\
(\%)\end{array}$ & $\begin{array}{c}\text { OR } \\
(95 \% \mathrm{CI})\end{array}$ & $p$ & $R$. \\
\hline $\begin{array}{c}\text { CD24 rs3838646 } \\
\text { P1527 TG/del } \\
\text { CD24 rs8734 C52T }\end{array}$ & $\begin{array}{l}120 \text { GCA patients } \\
195 \text { controls } \\
\text { Spanish patients } \\
\text { (Lugo region) }\end{array}$ & $\begin{array}{l}\text { TG or del } \\
\text { C or } \mathrm{T}\end{array}$ & $\begin{array}{l}\text { severe ischemic } \\
\text { complications * }\end{array}$ & & & $\begin{array}{l}\text { NS } \\
\text { NS }\end{array}$ & [60] \\
\hline $\begin{array}{l}\text { TLR4 rs4986790 } \\
+896 \mathrm{~A} / \mathrm{G}\end{array}$ & $\begin{array}{l}155 \text { GCA patients } \\
210 \text { controls Italian } \\
\text { patients (Reggio } \\
\text { Emilia) }\end{array}$ & A or $G$ & $\begin{array}{l}\text { patients with vs. } \\
\text { without visual loss } \\
\text { and/or cerebrovascular } \\
\text { accidents } \\
\text { patients with vs. } \\
\text { without visual ischemic }\end{array}$ & & & NS & [61] \\
\hline $\begin{array}{l}\text { TLR4 rs4986790 } \\
\quad+896 \mathrm{~A} / \mathrm{G}\end{array}$ & $\begin{array}{l}210 \text { GCA patients } \\
678 \text { controls } \\
\text { Spanish patients } \\
\text { (Lugo region, } \\
\text { Madrid, Granada) }\end{array}$ & A or $G$ & $\begin{array}{c}\text { complications } * * / \text { severe } \\
\text { ischemic } \\
\text { manifestations * } \\
\text { patients with visual } \\
\text { ischemic complications } \\
\text { vs. healthy } \\
\text { controls **/severe } \\
\text { ischemic } \\
\text { manifestations * }\end{array}$ & & & NS & [62] \\
\hline $\begin{array}{l}\text { TLR4 rs4986790 } \\
\quad+896 \mathrm{~A} / \mathrm{G} \\
\text { TLR4 rs4986791 } \\
\quad+1196 \mathrm{C} / \mathrm{T}\end{array}$ & $\begin{array}{l}72 \text { GCA patients } \\
126 \text { controls } \\
\text { Spanish patients } \\
\text { (Cantabria) }\end{array}$ & $\begin{array}{l}\text { A or } \mathrm{G} \\
\mathrm{C} \text { or } \mathrm{T}\end{array}$ & $\begin{array}{l}\text { at least one } \\
\text { relapse/recurrence, } \\
\text { number of relapses, } \\
\text { duration of GC } \\
\text { treatment, cumulative } \\
\text { prednisone dose; } \\
\text { ischemic } \\
\text { manifestations }\end{array}$ & & & $\begin{array}{l}\text { NS } \\
\text { NS }\end{array}$ & [63] \\
\hline $\begin{array}{c}\text { TLR9 rs187084 } \\
-1486 \mathrm{~T} / \mathrm{C} \\
\text { TLR9 rs5743836 } \\
-1237 \mathrm{~T} / \mathrm{C}\end{array}$ & $\begin{array}{l}97 \text { GCA patients } \\
128 \text { controls } \\
\text { Spanish patients }\end{array}$ & $\begin{array}{l}\text { TC vs. TT } \\
\text { CC vs. TT }\end{array}$ & $\begin{array}{l}\text { a shorter duration of } \\
\text { GC therapy } \\
\text { a higher number of } \\
\text { relapses/recurrences }\end{array}$ & & & 0.029 & [64] \\
\hline
\end{tabular}

HLA, Human leukocyte antigen; ICAM-1, Intercellular adhesion molecule-1; IFN- $\gamma$, Interferon gamma; INFGR1, Interferon gamma receptor 1; IL, Interleukin; IL-1Ra, IL-1 receptor antagonist; GC, glucocorticoids; GPIIIa, Platelet glycoprotein IIIa; MBL, Mannose-binding lectin; MCP-1, Monocyte chemoattractant protein-1; NFKB1, Nuclear factor of $\mathrm{k}$-light polypeptide gene enhancer in B cells 1; PTPN22, Protein tyrosine phosphatase non-receptor 22; TLR, Toll-like receptor; VEGF, Vascular endothelial growth factor. * At least one of the following complications: visual manifestations, cerebrovascular accidents, limb claudication, jaw claudication. ${ }^{* *}$ At least one of the following complications: permanent visual loss, amaurosis fugax, diplopia. ${ }^{* * *}$ At least one of the following complications: visual loss, jaw claudication, cerebrovascular accidents, aortic arch syndrome. NS-no statistical differences. \# values corrected by the number of comparisons.

Table 3. Genetic susceptibility to glucocorticoid treatment outcomes in polymyalgia rheumatica.

\begin{tabular}{|c|c|c|c|c|c|c|c|}
\hline Polymorphism & Population & $\begin{array}{l}\text { Allele or } \\
\text { Genotype }\end{array}$ & Clinical Features & $\begin{array}{l}\text { Allele Freq. } \\
(\%)\end{array}$ & $\begin{array}{c}\text { OR } \\
(95 \% \mathrm{CI})\end{array}$ & $p$ & $R$. \\
\hline HLA-DRB1 & $\begin{array}{l}89 \text { PMR patients } \\
\text { Spanish patients } \\
\text { (Cantabria region) }\end{array}$ & $\begin{array}{l}{ }^{*} 09 \\
* 0101\end{array}$ & $\begin{array}{l}\text { patients with vs. } \\
\text { without relapses } \\
\text { patients with vs. } \\
\text { without relapses }\end{array}$ & $\begin{array}{c}5.6 \text { vs. } 0 \\
11.1 \text { vs. } 8.3\end{array}$ & $1.4(0.4-5.2)$ & $\begin{array}{l}0.04 \\
0.07\end{array}$ & [45] \\
\hline HLA-DRB1 & $\begin{array}{l}91 \text { PMR patients } \\
\text { Italian patients } \\
\text { (Reggio Emilia) }\end{array}$ & $\begin{array}{l}{ }^{*} 01 \\
{ }^{*} 10\end{array}$ & $\begin{array}{l}\text { patients with vs. } \\
\text { without relapses } \\
\text { patients with vs. } \\
\text { without } \\
\text { relapses/recurrences } \\
\text { patients with vs. } \\
\text { without } \\
\text { relapses/recurrences }\end{array}$ & 11.1 vs. 4.2 & $\begin{array}{c}\text { RH 1.56 } \\
(0.54-4.5) \\
\text { RH 2.63 } \\
(0.23-30.11)\end{array}$ & 0.005 & [66] \\
\hline IL-6 -174 G/C & $\begin{array}{l}84 \text { iPMR patients } \\
\text { Spanish patients } \\
\text { (Lugo region) }\end{array}$ & $\mathrm{G}$ or $\mathrm{C}$ & $\begin{array}{c}\text { patients with vs. } \\
\text { without } \\
\text { relapses/recurrences }\end{array}$ & & & NS & [52] \\
\hline IL-6 -174 G/C & $\begin{array}{l}112 \text { iPMR patients } \\
\text { Italian patients } \\
\text { (Reggio Emilia) }\end{array}$ & G or C & $\begin{array}{l}\text { patients with vs. } \\
\text { without } \\
\text { relapses/recurrences }\end{array}$ & & & NS & [67] \\
\hline
\end{tabular}


Table 3. Cont.

\begin{tabular}{|c|c|c|c|c|c|c|c|}
\hline Polymorphism & Population & $\begin{array}{l}\text { Allele or } \\
\text { Genotype }\end{array}$ & Clinical Features & $\begin{array}{l}\text { Allele Freq. } \\
(\%)\end{array}$ & $\begin{array}{c}\text { OR } \\
(95 \% \mathrm{CI})\end{array}$ & $p$ & $R$. \\
\hline \multirow{3}{*}{$\begin{array}{l}\text { TLR4 rs4986791 } \\
+1196 \mathrm{C} / \mathrm{T}\end{array}$} & \multirow{3}{*}{$\begin{array}{l}164 \text { PMR patients } \\
\text { Spanish patients }\end{array}$} & $\mathrm{CC}$ & $\begin{array}{l}\text { cumulative dose of } \\
\text { prednisone in PMR } \\
\text { patients }\end{array}$ & & $\begin{array}{l}5.6 \pm 4.8 \mathrm{vs} \\
2.1 \pm 0.5 \mathrm{~g}\end{array}$ & 0.031 & \multirow[t]{3}{*}{ [68] } \\
\hline & & $\mathrm{CC}$ & $\begin{array}{c}\text { duration of prednisone } \\
\text { treatment in PMR } \\
\text { patients }\end{array}$ & & $\begin{array}{c}41.8 \pm 39.3 \\
\text { vs. } 16.0 \pm \\
10.4 \text { months }\end{array}$ & 0.10 & \\
\hline & & $\mathrm{CC}$ & $\begin{array}{l}\text { a number of relapses in } \\
\text { PMR patients }\end{array}$ & & $\begin{array}{c}0.9 \pm 1.3 \text { vs. } \\
0.0 \pm 0.0\end{array}$ & 0.07 & \\
\hline CCR5 $\triangle 32$ & $\begin{array}{c}88 \text { PMR patients } 86 \\
\text { controls Italian } \\
\text { patients (Reggio } \\
\text { Emilia) }\end{array}$ & $\begin{array}{l}\text { CCR5 or } \\
\text { CCR5 } \triangle 32\end{array}$ & $\begin{array}{l}\text { initial and cumulative } \\
\text { dose of prednisone, } \\
\text { duration of therapy, } \\
\text { relapse/recurrence in } \\
\text { PMR patients vs. } \\
\text { healthy controls }\end{array}$ & & & NS & [69] \\
\hline $\begin{array}{l}\text { IL-1RN } 86 \text { bp } \\
\text { VNTRs within the } \\
\text { second intron }\end{array}$ & $\begin{array}{l}139 \text { iPMR patients } \\
437 \text { controls } \\
\text { Spanish patients } \\
\text { (Cantabria region) }\end{array}$ & $\begin{array}{l}{ }^{*} 1 \text { (four } \\
\text { repeats) } \\
\text { or }{ }^{*} 2 \text { (two } \\
\text { repeats) }\end{array}$ & $\begin{array}{l}\text { relapses/recurrences, } \\
\text { number of relapses, } \\
\text { duration of } \\
\text { corticosteroid therapy, } \\
\text { cumulative prednisone } \\
\text { dose }\end{array}$ & & & NS & [56] \\
\hline IL-1A +4845 C/T & & $\mathrm{C}$ or $\mathrm{T}$ & relapses/recurrences, & & & NS & \\
\hline IL-1B -511 & 92 PMR patients 79 & $* 1$ or $* 2$ & duration of & & & NS & \\
\hline IL-1B +3954 & controls Italian & $* 1$ or $* 2$ & corticosteroid therapy, & & & NS & [70] \\
\hline TNFA -308 & $\begin{array}{l}\text { patients (Reggio } \\
\text { Fmilia) }\end{array}$ & $* 1$ or $* 2$ & cumulative prednisone & & & NS & \\
\hline IL-1RN Intron 2 & & $* 1$ or $* 2$ & dose & & & NS & \\
\hline ICAM-1 241 R/G & 72 iPMR patients & R or G & $\begin{array}{l}\text { patients with vs. } \\
\text { without relapse }\end{array}$ & & & NS & \\
\hline ICAM-1 $469 \mathrm{~K} / \mathrm{E}$ & $\begin{array}{l}\text { Spanish patients } \\
\text { (Lugo region) }\end{array}$ & $\mathrm{K}$ or $\mathrm{E}$ & $\begin{array}{l}\text { patients with vs. } \\
\text { without relapse }\end{array}$ & & & NS & [71] \\
\hline HLA-DRB1 & & *0401 & $\begin{array}{l}\text { patients with vs. } \\
\text { without relapse }\end{array}$ & & $7.2(1.5-35.5)$ & 0.01 & \\
\hline $\begin{array}{l}\text { HLA-DRB1 and } \\
\text { ICAM-1 } 241\end{array}$ & & $\begin{array}{l}* 0401 \text { and } \\
\text { GG }\end{array}$ & $\begin{array}{l}\text { patients with vs. } \\
\text { without relapse }\end{array}$ & & $\begin{array}{c}15.2 \\
(2.3-99.5)\end{array}$ & $\begin{array}{l}0.005 \\
0.03^{\#}\end{array}$ & \\
\hline ICAM-1 241 R/G & $\begin{array}{l}91 \text { iPMR patients } \\
228 \text { controls Italian } \\
\text { patients (Reggio } \\
\text { Emilia) }\end{array}$ & $\begin{array}{l}\mathrm{RR}+\mathrm{GR} \\
\text { vs. GG }\end{array}$ & relapses/recurrences & & $1.6(1.1-2.4)$ & 0.01 & [72] \\
\hline IL-10 -592C/A & 168 iPMR patients & C or $\mathrm{A}$ & relapses/recurrences, & & & NS & \\
\hline IL-10 -1082A/G & $\begin{array}{l}124 \text { controls } \\
\text { Spanish patients } \\
\text { (Cantabria region) }\end{array}$ & $A$ or $G$ & $\begin{array}{l}\text { number of relapses, } \\
\text { duration of } \\
\text { corticosteroid therapy, }\end{array}$ & & & NS & [73] \\
\hline NOS3 -786T/C & $\begin{array}{l}78 \text { iPMR patients } \\
2061 \text { controls } \\
\text { German patients } \\
\text { (Heidelberg) }\end{array}$ & $\mathrm{T}$ or $\mathrm{C}$ & $\begin{array}{l}\text { cumulative prednisone } \\
\text { dose } \\
\text { steroid responsiveness }\end{array}$ & & & NS & [74] \\
\hline
\end{tabular}

CCR5, CC chemokine receptor 5; HLA, Human leukocyte antigen; ICAM-1, Intercellular adhesion molecule-1; IL, Interleukin; IL-1Ra, IL-1 receptor antagonist; iPMR, Isolated PMR; NOS3, Nitric oxide synthase 3; TLR, Toll-like receptor; TNFA, Tumor necrosis factor $\alpha$. NS- no statistical differences. \# values corrected by the number of comparisons.

\subsection{Human Leukocyte Antigen (HLA)}

Rauzy et al. observed a significantly higher frequency of HLA-DRB1*04 in a group of GCA patients studied over two years. An association of GCA with HLA-DRB1*04 seemed to accompany GC resistance [41]. According to Dababneh et al., HLA-DRB1*04 was particularly pronounced in those Spanish patients with severe visual complications [42]. This supports the idea proposed by Rauzy et al. [43] that HLA-DRB1*04 may be a genetic marker of severity in GCA. In contrast, although Combe et al. described an increased frequency of HLA-DRB1*04 in their case series of 42 French patients with GCA, they did not find any significant relationship between the HLA-DRB1 gene and markers of disease severity and activity. These discrepancies may be related to the different ethnic backgrounds of the investigated groups.

HLA-DR4 is associated with rheumatoid arthritis (RA), in particular with the prognostically more severe form (early onset RA). Rheumatoid factor seronegative elderly onset RA and isolated PMR patients do not seem to be associated with DRB1*04 or *01. Instead, both pathological states 
appear to have a similar genetic basis (disease susceptibility) such as association with DRB1*13/14 [75]. Salvarani et al. studied the risk factors associated with relapse/recurrence in PMR, aiming at clinical and laboratory parameters, as well as HLA-DRB1* antigens using a multivariate analysis. This work showed that increased ESR at diagnosis ( $>72 \mathrm{~mm} \mathrm{1st} \mathrm{h)} \mathrm{along} \mathrm{with} \mathrm{the} \mathrm{presence} \mathrm{of} \mathrm{the} \mathrm{rheumatoid} \mathrm{epitope}$ encoded by a non-DR4 (particularly DR1) allele are independent risk factors of relapse/recurrence. These results support the presumption that DR1 may be implicated in the prognosis of PMR patients, helping to identify those with a more severe form of the disease [66].

\subsection{Intercellular Adhesion Molecule-1}

Regarding ICAM-1 gene polymorphisms, the mutation of glycine $(G)$ with arginine $(R)$ at codon 241 was found to contribute to an increased risk of PMR relapse/recurrence in Italian patients. $G / R$ polymorphism occurs in the domain 3 of ICAM-1, which is involved in the interaction with leukocyte integrins. Therefore, it was proposed that R241 mutation could confer a more effective adhesive function of ICAM-1, with a subsequent impact on the inflammatory response [72], although discordant data have been also published. Amoli et al. did not confirm ICAM-1 241 polymorphism as an independent risk factor of PMR severity [71], the potential explanation of which being that both groups studied consisted of two different populations varying in ethnic background, since Italian and Spanish donors were examined. Moreover, the association between the HLA-DRB1*0401 allele and the risk of relapse was described in Spaniards with PMR. All relapsed patients with HLA-DRB1*0401 also carried the GG genotype of ICAM-1 at codon 241 [71].

In the case of GCA severity, visual manifestations were not associated with polymorphism of ICAM-1 at codon 241 or codon 469 (biallelic polymorphism Lys/Glu) in patients from northwest Spain. Additionally, an association between HLA-DRB1*04 and visual complications was observed, but no interaction between HLA-DRB1*04 and ICAM-1 polymorphism could be found in the series of examined patients [49].

\subsection{Interleukin 6}

IL-6 is a significantly produced cytokine in PMR and GCA patients, which is considered as a potential marker of disease activity sensitive to GC treatment [76]. IL-6 expression is affected by promoter polymorphism at position $-174 \mathrm{G} / \mathrm{C}$ in the IL-6 gene. It was found that patients with isolated PMR and homozygous for the $C$ allele had elevated serum levels of IL- 6 as compared to carriers of the GC and GG genotypes, but no differences among genotypes were reported in terms of relapse/recurrence frequency [67]. Next, the G/C 174 genotype was not associated with the clinical features of GCA demonstrated as ischemic complications [51]. As was the case with the Italian patients from the previous two studies, no associations between polymorphism at $-174 \mathrm{G} / \mathrm{C}$ of IL- 6 with disease severity were observed in a cohort of Spanish patients with isolated PMR nor in GCA patients [52].

\subsection{RANTES and CC Chemokine Receptor 5}

The chemokine RANTES (Regulated upon Activation, Normal T cell Expressed and presumably Secreted) activates monocytes and memory $\mathrm{T}$ cells, the main cell types infiltrating PMR synovial tissue via interaction with the CC chemokine receptor 5 (CCR5) [69]. The gene encoding CCR5 is polymorphic with the identified non-functional 32-bp deletion allele [77]. It has been hypothesized that polymorphism in the CCR5 gene might help explain the higher circulating levels of RANTES and the severity of disease in PMR patients. Nevertheless, according to the results obtained from the study with PMR patients of Italian origin, no significant association was observed between the CCR5 genotype and the therapeutic outcomes measured as duration of therapy, frequency of relapse/recurrence, as well as the initial and cumulative prednisone dose [69]. 


\subsection{Monocyte Chemoattractant Protein-1}

Monocyte chemoattractant protein-1 (MCP-1, CCL2) is another CC chemokine which attracts and activates monocytes and T cells [57]. MCP-1 mRNA levels were found to be elevated in temporal artery samples gained from GCA patients as compared to controls ( $31 \pm 15.6$ vs. $0.44 \pm 0.1, p=0.0001$ ), with even higher levels found in patients who had suffered two or more relapses than in patients with no relapse $(127 \pm 82$ vs. $11 \pm 5.5, p=0.0233)$. MCP- 1 mRNA concentration also correlated with the cumulative prednisolone dose $(R=0.533, p=0.0024)$. These findings indicate that MPC-1 may participate in the persistence of inflammation in GCA patients [78]. Further, three common single nucleotide polymorphisms (SNPs) in the MCP-1 gene were studied in the group of GCA Spanish patients, but none of the SNPs was associated with disease severity presenting as visual manifestations [57].

\subsection{Interferon Gamma}

Interferon gamma (IFN- $\gamma$ ) is a cytokine involved in the pathogenesis of only GCA but not PMR as revealed by histological analyses of the temporal arteries of both PMR patients without evidence of arteritis as well as GCA patients. This results indicate the role of this cytokine in the progression of overt arteritis [14]. Dinucleotide (CA) repeat polymorphism within the first intron of the IFN- $\gamma$ gene (INFG) was assessed in association with the clinical features of Spanish patients suffering from GCA [54]. It was shown that GCA patients with visual ischemic manifestations were characterized by the presence of a lower frequency of INFG allele *4 (a low IFN- $\gamma$ producer) as compared with GCA patients without visual ischemic complications. On the contrary, allele $* 3$ (a high IFN- $\gamma$ producer) was revealed in a higher frequency among GCA patients with visual ischemic manifestations, suggesting the relevant role of functional polymorphisms of the INFG in the clinical severity of GCA [54]. Later, the receptor for INF- $\gamma$ was also interrogated, however, none of the three tested single nucleotide polymorphisms $(-611 \mathrm{~A} / \mathrm{G},+189 \mathrm{G} / \mathrm{C}$ and $+95 \mathrm{C} / \mathrm{T})$ of the IFNGR1 gene provided any evidence of linkage with clinical manifestations of GCA [53].

\subsection{Interleukin 2 and Interleukin 21}

The phenotypic expression of GCA was disclosed to be associated with SNP, referred to as rs6822844 G/T and situated in the intergenic region between IL-2 and IL-21 genes. In this regard, the increased frequency of the minor allele T occurred in patients with severe ischemic events as well as in patients experiencing jaw claudication. It has been proposed that the role of this noncoding polymorphism is involved in microRNA production, with a subsequent alteration in target gene expression [47].

\subsection{Interleukin 1 Receptor Antagonist and Interleukin 10}

Anti-inflammatory mechanisms, including the effects of receptor antagonists, e.g., the IL-1 receptor antagonist (IL-1Ra) and anti-inflammatory cytokines such as IL-10, may favor disease treatment outcomes by the delicate balancing of pro-inflammatory cytokines.

Although IL-1Ra binds to the IL-1 receptor, it does not trigger any intracellular response. Since it has been suggested that genetic polymorphisms of IL-1Ra may result in differential in vivo protein levels, the impact of a tandem-repeat polymorphism within intron 2 of the IL1-Ra gene (IL1-RN) on the severity of PMR and GCA was investigated [56]. Interestingly, although the IL-1RN² allele was proposed to be responsible for higher plasma levels of IL-Ra, and although the IL- $1 R N^{*} 2 / 2$ genotype is more distributed among PMR patients compared to GCA patients, no associations were found between the presence of the IL- $1 \mathrm{RN}^{*} 1$ or IL- $1 \mathrm{RN}^{*} 2$ allele and the number of relapses, duration of GC treatment, or the cumulative prednisone dose among Spanish patients with PMR or GCA [56].

Another work focused on an analysis of several polymorphisms regulating the expression of genes coding cytokines, namely IL-1A (+4845), IL-1B (-511), IL-1B (+3954), the TNF $\alpha$ gene $(-308)$ and 
IL-1RN Intron 2. The reported results support no associations between these gene variants and disease severity in PMR patients of Italian origin [70].

IL-10 is Th2-derived cytokine which suppresses the production of pro-inflammatory Th1-derived IFN- $\gamma$. IL-10 promoter polymorphisms $-592 \mathrm{C} / \mathrm{A}$ and $-1082 \mathrm{~A} / \mathrm{G}$ have been studied in terms of the prognosis of PMR and GCA patients, but no association between these polymorphisms and clinical phenotype was found $[58,59,73]$.

\subsection{Corticotropin-Releasing Hormone}

The hypothalamic production of the corticotropin-releasing hormone (CRH) is stimulated by inflammatory cytokines like IL-1, IL-6 and TNF. In turn, CRH helps to control homeostasis during immune-meditated inflammatory stress. The Spanish study regarding the distribution of two biallelelic CRH promoter polymorphisms localized at positions 1273 (alleles A1 and A2) and 225 (alleles B1 and B2) revealed no association with the severity of disease in patients with isolated PMR. This was not the case in GCA patients from the same region (Lugo, Spain), where a higher frequency of the allele A2 was associated with the development of visual ischemic manifestations. These data, however, were obtained from a small group of GCA patients with visual complications $(n=14)$, a fact which limits the unequivocal interpretation of the results [79].

\subsection{Toll-like Receptor 4 and 9}

Toll-like receptors (TLRs) are important components of innate and acquired immune responses. Among these, TLR4 gene has been proposed as a genetic marker of clinical outcomes in patients with PMR. As assessed by an analysis of its two gene polymorphisms Asp299Gly and Thr399Ile, the Thr399Ile CC genotype was associated with the administration of a higher cumulative dose of prednisone in PMR patients as compared to healthy controls (5.6 \pm 4.8 vs. $2.1 \pm 0.5 \mathrm{~g} ; p=0.031$ ). These findings can be explained by longer prednisone treatment ( $41.8 \pm 39.3$ vs. $16.0 \pm 10.4$ months; $p=0.10$ ), and a higher number of relapses $(0.9 \pm 1.3$ vs. $0.0 \pm 0.0 ; p=0.07)$ for Thr399Ile CC genotype. However, when the functional consequences of TLR4 variants were examined, none of these revealed a different expression on B cells, $\mathrm{T}$ cells or monocytes, or showed a distinct response in intracellular cytokine production using stimulated monocytes [68].

Only three studies, all carried out on Mediterranean population, have been published so far looking for the association among TLR4 gene polymorphisms and clinical features of GCA. However, reported results did not find any association of distinct polymorphisms with clinical manifestations such as ischemic symptoms or the prognosis of the disease [61-63].

As shown in another study, GCA patients carrying the TC genotype of the TLR9 gene T-1486C polymorphism needed a shorter duration of GC treatment. Next, patients with the CC genotype of the TLR9 T-1237C polymorphism suffered from an increased number of relapses/recurrences suggesting a role of TLR9 gene variants in prognosis of GCA. On the other hand, studied polymorphisms did not have any impact on therapeutic outcomes of PMR patients [64].

\subsection{Nuclear Factor of $\kappa B 1$}

The nuclear factor of the $\kappa$-light polypeptide gene enhancer in B cells 1 (NFkB1) is a key activator of genes implicated in immune processes. NFKB is also the main target of GC treatment [31]. Of note, NFKB1 promoter polymorphism described as the presence or absence of 4-base pair deletion (-94ins/delATTG) has been associated with altered NFKB1 expression. Nevertheless, one population study showed the unlikelihood that 94ins/delATTG NFKB1 promoter polymorphism has any impact on clinical manifestations of GCA [50].

\subsection{Protein Tyrosine Phosphatase Non-Receptor 22}

Protein tyrosine phosphatases together with protein tyrosine kinases tightly orchestrate signal transduction in cells, with the deregulation of cell signaling supposed as being implicated in 
inflammatory pathological processes. One lymphoid-specific phosphatase (Lyp) encoded by the PTPN22 (protein tyrosine phosphatase non-receptor 22) gene has been studied regarding its involvement in severe ischemic manifestations among GCA patients. PTPN22 is a polymorphic gene at position C1858T, which plays a role in T cell activity. In one Spanish study, however, no evidence was found related to any association between PTPN22 polymorphism and clinical expression of GCA [48]. In the same line, meta-analysis of four independent cohorts (911 patients in total) on two PTPN22 polymorphisms (rs2476601 and rs33996649) showed no differences among GCA patient subphenotypes. Nevertheless, when subpopulations of GCA patients were compared to healthy patients (case vs. control), minor allele (rs2476601) was significantly associated with both GCA patients suffering from visual ischemic manifestations and irreversible occlusive disease [80].

\subsection{Vascular Endothelial Growth Factor}

In patients with active PMR/GCA, elevated circulating vascular endothelial growth factor (VEGF) levels have been described. Increased VEGF serum concentrations were reduced by GC treatment [81]. VEGF represents an important pro-angiogenic factor controlling neovascularization. The role of two VEGF promoter polymorphisms were assessed regarding ischemic complications among GCA patients of Spanish origin. Interestingly, the VEGF $-634 \mathrm{G}$ allele was found more frequently than the $\mathrm{C}$ allele in GCA patients with severe ischemic manifestations as compared to in the remaining patients or controls. Moreover, a higher risk of severe ischemic complications was detected among patients carrying the 634 GG genotype; however, no association was found regarding another studied polymorphism G1154A [55]. Nevertheless, in disagreement with this Spanish study, results with Italian GCA patients with or without ischemic manifestations revealed that the distribution of VEGF G634C polymorphism showed no significant differences [82]. These disparities among results again support the role of different genetic backgrounds in severity of disease among diverse populations.

\subsection{Platelet Glycoprotein IIIa}

Although visual manifestations in GCA are assigned to occlusive vasculopathy as a result of intimal hyperplasia, thrombotic occlusion may also be involved. Indeed, cranial ischemic complications have been associated with PlA2 allele (rs5918) of the platelet glycoprotein IIIa (GPPIIIA), a subunit of the platelet membrane receptor involved in thrombus formation. GCA patients being homozygous for PlA2 allele have been in increased risk of visual loss [65].

\subsection{Interleukin $17 \mathrm{~A}$}

IL-17A, often referred to as IL-17, is a pro-inflammatory cytokine. The IL-17-triggered release of IL-6 activates the STAT3 pathway, which further activates the NFKB pathway [83]. Marquez et al. produced evidence of an association between GCA susceptibility and the IL-17A G197A (rs2275913) and G8065A (rs7747909) SNPs. This evidence points to the role of IL-17-producing Th17 cells in this type of vasculitis [84]. Indeed, Th17 cells have been found in GCA lesions [85]. Furthermore, a higher expression of IL-17A as well as other cytokines implicated in Th17 differentiation and function has been discovered in temporal artery biopsies taken from GCA patients $[38,83,86]$. IL-17-producing Th17 cells have been shown to contribute to systemic and vascular symptoms of GCA, but through a different pathogenic pathway than that mediated by IFN- $\gamma$-producing Th1 cells. Moreover, it has been suggested that Th17 cells exert more important influence in the early disease process, whereas Th1 cells seem to be more involved in the chronic disease [87].

The study by Deng et al. showed not only the crucial role that Th17 cells have in the development of GCA, but also provided evidence that GCs effectively suppress Th17 cells [85]. Espígol-Frigolé et al. confirmed the high relevance of Th17 cells in the immunopathology of GCA, as well as in the response to GC treatment [86]. On the contrary, GCs have shown an effect neither on Th1 cells [85] nor on IL-9-producing Th9 cells [88]. These findings may indicate a potential implication of Th1 and Th9 cells in GC resistance. As stated above, Th17 cells are sensitive to GC-mediated suppression, thus 
the Th17/Th1 ratio may be a potential marker for the assessment of GC resistance in GCA patients (Figure 2) $[85,86]$.

It is also worth mentioning that IL-17A can act as a pro-atherogenic factor. Pre-existing atherosclerosis has been shown as a potential risk factor for ischemic complications in GCA. Therefore, it is tempting to assume that IL-17A might also affect the severity of this type of vasculitis, thus presenting a promising therapeutic target for GCA [84]. In addition, IL-17A gene polymorphisms are promising candidate markers for the study of GC treatment outcomes in GCA [84].

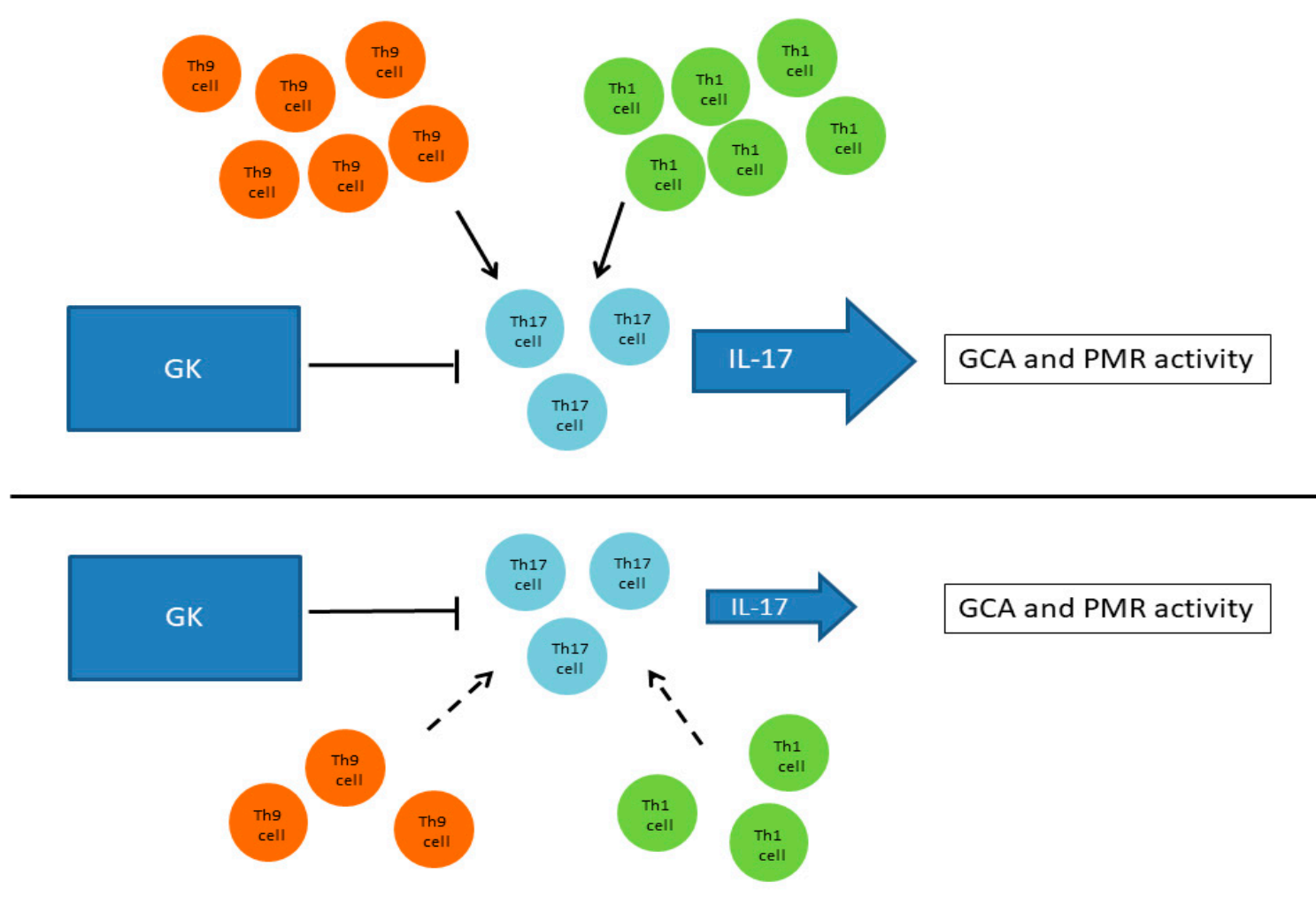

Figure 2. Potential involvement of Th cell subpopulations in GC resistance. Glucocorticoids effectively suppress Th17 cell type but have no effect either on Th1 cells, or on the IL-9-producing Th9 cell. This may indicate the potential implication of Th9 and Th1 cells in glucocorticoid resistance.

\subsection{Other Genetic Associations}

Although GCA is considered complex polygenic disease, in which more polymorphic genes are supposed to affect its clinical manifestation, many studies did not succeed to find associations between clinical expression of GCA and gene polymorphisms such as ITGAM rs1143679 [89], STAT4 rs7574865 [90], IL2RA rs2104286 [91], 6q23/TNFAIP3 gene region rs6920220 [92], TRAF1/C5 region rs10818488 and rs2900180 [93], TRAF6 rs540386 [94], IL23R rs1343151, IL12RB2 rs3790567 [95], CSK rs1378942 and rs34933034 [80], CD226 rs727088, rs34794968, and rs763361 [96], MPO rs2333227 [97], C-reactive protein rs1417938, rs1800947, rs1205, and rs3093059 [98], CCR6 rs3093024 [99], IRF5 rs2004640 and 5-bp CGGGG insertion/deletion [100], BANK1 rs17266594, rs10516487, and rs3733197 [101], endothelial nitric oxide synthase (eNOS) rs1799983 and 4a/b polymorphism in intron 4 (variable number of tandem-repeats, VNTRs) [102].

Some other reports showed marginally significant associations of polymorphism either with susceptibility to visual ischemic manifestations or severe ischemic manifestations within a cohort of GCA patients. The first is exemplified by the minor allele T of CD40 (rs1883832 C/T polymorphism) [103], the latter is true for A allele of rs13277113 (A/G), which is located between C8orf13 and B-lymphoid kinase (BLK) genes [104]. 


\subsection{Deregulated Cell Signaling Pathways in PMR and GCA}

It is currently accepted that the cytokine axes such as IL-12/IFN- $\gamma$ and IL-6/IL-17 are the most relevant pathways involved both in medium and large vessel vasculitis as well as in vasculitis associated with psoriasis [105-107]. In GCA and PMR, some recent observations have suggested that these pathways may lead to different disease outcomes [83]. For example, elevated Th1 response, in which increased IFN- $\gamma$ levels would trigger strong macrophage activation, appears to be related to granulomatous inflammation and blindness. Nevertheless, polarization of the response to Th17 is associated with the presence of PMR, with higher relapse rates, as well as with lower patient susceptibility to developing blindness.

\section{Conclusions}

Regarding PMR and GCA patients, our current understanding of GC resistance associated with MHC and non-MHC gene polymorphisms is relatively limited. One reason for this is that most conducted clinical studies enrolled only small patient groups with the lack of statistical power. Additionally, the primary goal of most clinical studies was aimed at disease susceptibility. The HLA-DRB1*04 allele carriage appears to be the promising prognostic factor for GC resistance at least within specific ethnic populations. Further effort should focus among others on ICAM-1, TLR4 and 9, VEGF, and INFG polymorphisms since recent preliminary findings have suggested their contribution to GC resistance. Although IL-6 is potential serum marker, but polymorphisms of IL-6 gene is not currently found as a genetic marker of PMR/GCA disease activity. The detected genetic associations will require further validation in larger populations of different ethnicity. Such approaches may result in promising therapeutic implications, since the findings could help to identify patients as potential responders or non-responders to GC treatment, with concomitant consequences in therapeutic strategies.

Author Contributions: Conceptualization, T.S. (Tomas Smutny) and T.S. (Tomas Soukup); funding acquisition, T.S. (Tomas Soukup) and P.P.; writing—original draft preparation, T.S. (Tomas Smutny) and T.S. (Tomas Soukup); writing-review and editing, T.S. (Tomas Smutny), T.S. (Tomas Soukup), T.V., I.B. and P.P.; project administration, T.S. (Tomas Smutny), T.S. (Tomas Soukup), T.V., I.B. and P.P. All authors read and approved the final manuscript.

Funding: This research was funded by the grant MH CZ-DRO UHHK, grant number 00179906; Charles University research projects (PROGRES Q40-15, PROGRES Q47) and the project EFSA-CDN (No. CZ.02.1.01/0.0/0.0/16_019/0000841) co-funded by ERDF.

Conflicts of Interest: The authors declare no conflict of interest.

\section{Abbreviations}

$\begin{array}{ll}\text { AP1 } & \text { Activator protein 1 } \\ \text { CCR5 } & \text { CC chemokine receptor 5 } \\ \text { BANK1 } & \text { B cell scaffold protein with ankyrin repeats 1 } \\ \text { BLK } & \text { B-lymphoid kinase } \\ \text { CRH } & \text { Corticotropin-releasing hormone } \\ \text { CRP } & \text { C-reactive protein } \\ \text { ERK } & \text { Extracellular signal-regulated kinase } \\ \text { ESR } & \text { Erythrocyte sedimentation rate } \\ \text { GCA } & \text { Giant cell arteritis } \\ \text { GCs } & \text { Glucocorticoids } \\ \text { GPIIIa } & \text { platelet glycoprotein IIIa } \\ \text { GR } & \text { Glucocorticoid receptor } \\ \text { HLA } & \text { Human leukocyte antigen } \\ \text { ICAM-1 } & \text { Intercellular adhesion molecule-1 } \\ \text { IFN- } \gamma & \text { Interferon gamma } \\ \text { INFG } & \text { IFN- } \gamma \text { gene } \\ \text { IL } & \text { Interleukin }\end{array}$




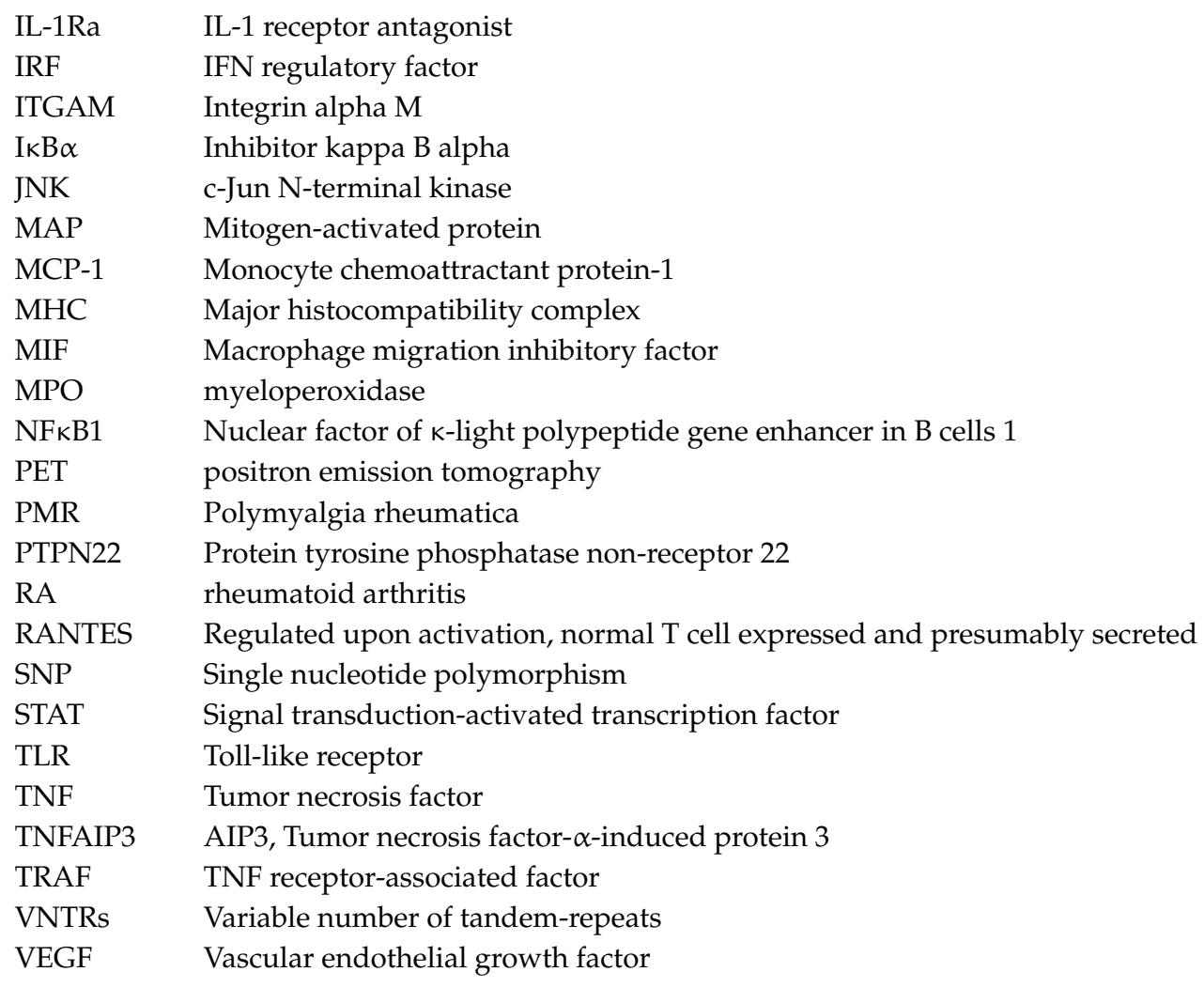

\section{References}

1. Patel, M.; Forsyth, D.R. Polymyalgia rheumatica and giant cell arteritis. J. Clin. Gerontol. Geriatr. 2011, 2, 7-12. [CrossRef]

2. Rooney, P.J.; Rooney, J.; Balint, G.; Balint, P. Polymyalgia rheumatica: 125 years of epidemiological progress? Scott. Med. J. 2015, 60, 50-57. [CrossRef]

3. Nesher, G.; Breuer, G.S. Giant Cell Arteritis and Polymyalgia Rheumatica: 2016 Update. Rambam. Maimonides Med. J. 2016, 7. [CrossRef]

4. Blockmans, D.; De Ceuninck, L.; Vanderschueren, S.; Knockaert, D.; Mortelmans, L.; Bobbaers, H. Repetitive 18-fluorodeoxyglucose positron emission tomography in isolated polymyalgia rheumatica: A prospective study in 35 patients. Rheumatology (Oxford) 2007, 46, 672-677. [CrossRef] [PubMed]

5. Moosig, F.; Czech, N.; Mehl, C.; Henze, E.; Zeuner, R.A.; Kneba, M.; Schroder, J.O. Correlation between 18-fluorodeoxyglucose accumulation in large vessels and serological markers of inflammation in polymyalgia rheumatica: A quantitative PET study. Ann. Rheum. Dis. 2004, 63, 870-873. [CrossRef]

6. Cantini, F.; Niccoli, L.; Storri, L.; Nannini, C.; Olivieri, I.; Padula, A.; Boiardi, L.; Salvarani, C. Are polymyalgia rheumatica and giant cell arteritis the same disease? Semin. Arthritis. Rheum. 2004, 33, 294-301. [CrossRef]

7. Gonzalez-Gay, M.A.; Matteson, E.L.; Castaneda, S. Polymyalgia rheumatica. Lancet 2017, 390, $1700-1712$. [CrossRef]

8. Gonzalez-Gay, M.A.; Amoli, M.M.; Garcia-Porrua, C.; Ollier, W.E. Genetic markers of disease susceptibility and severity in giant cell arteritis and polymyalgia rheumatica. Semin. Arthritis. Rheum. 2003, 33, 38-48. [CrossRef]

9. Hellmann, D.B. Giant cell arteritis, polymyalgia rheumatica and Takayasu's arteritis. In Kelley's Textbook of Rheumatology, 9th ed.; Firestein, G.S., Budd, R.C., Gabriel, S.E., Mcinnes, I.B., O’Dell, J.R., Eds.; Elsevier Saunders: Philadelphia, PA, USA, 2013; Volume 2, pp. 1461-1480.

10. Carroll, S.C.; Gaskin, B.J.; Danesh-Meyer, H.V. Giant cell arteritis. Clin. Exp. Ophthalmol. 2006, 34, $159-173$. [CrossRef] [PubMed] 
11. Hernandez-Rodriguez, J.; Segarra, M.; Vilardell, C.; Sanchez, M.; Garcia-Martinez, A.; Esteban, M.J.; Grau, J.M.; Urbano-Marquez, A.; Colomer, D.; Kleinman, H.K.; et al. Elevated production of interleukin-6 is associated with a lower incidence of disease-related ischemic events in patients with giant-cell arteritis: Angiogenic activity of interleukin-6 as a potential protective mechanism. Circulation 2003, 107, 2428-2434. [CrossRef] [PubMed]

12. Samson, M.; Audia, S.; Fraszczak, J.; Trad, M.; Ornetti, P.; Lakomy, D.; Ciudad, M.; Leguy, V.; Berthier, S.; Vinit, J.; et al. Th1 and Th17 lymphocytes expressing CD161 are implicated in giant cell arteritis and polymyalgia rheumatica pathogenesis. Arthritis. Rheum. 2012, 64, 3788-3798. [CrossRef]

13. Alvarez-Rodriguez, L.; Lopez-Hoyos, M.; Mata, C.; Marin, M.J.; Calvo-Alen, J.; Blanco, R.; Aurrecoechea, E.; Ruiz-Soto, M.; Martinez-Taboada, V.M. Circulating cytokines in active polymyalgia rheumatica. Ann. Rheum. Dis. 2010, 69, 263-269. [CrossRef] [PubMed]

14. Weyand, C.M.; Hicok, K.C.; Hunder, G.G.; Goronzy, J.J. Tissue cytokine patterns in patients with polymyalgia rheumatica and giant cell arteritis. Ann. Intern. Med. 1994, 121, 484-491. [CrossRef]

15. Dejaco, C.; Singh, Y.P.; Perel, P.; Hutchings, A.; Camellino, D.; Mackie, S.; Abril, A.; Bachta, A.; Balint, P.; Barraclough, K.; et al. 2015 Recommendations for the management of polymyalgia rheumatica: A European League Against Rheumatism/American College of Rheumatology collaborative initiative. Ann. Rheum. Dis. 2015, 74, 1799-1807. [CrossRef] [PubMed]

16. Mukhtyar, C.; Guillevin, L.; Cid, M.C.; Dasgupta, B.; de Groot, K.; Gross, W.; Hauser, T.; Hellmich, B.; Jayne, D.; Kallenberg, C.G.; et al. EULAR recommendations for the management of large vessel vasculitis. Ann. Rheum. Dis. 2009, 68, 318-323. [CrossRef] [PubMed]

17. Salvarani, C.; Cantini, F.; Niccoli, L.; Macchioni, P.; Consonni, D.; Bajocchi, G.; Vinceti, M.; Catanoso, M.G.; Pulsatelli, L.; Meliconi, R.; et al. Acute-phase reactants and the risk of relapse/recurrence in polymyalgia rheumatica: A prospective followup study. Arthritis. Rheum. 2005, 53, 33-38. [CrossRef] [PubMed]

18. Kremers, H.M.; Reinalda, M.S.; Crowson, C.S.; Zinsmeister, A.R.; Hunder, G.G.; Gabriel, S.E. Relapse in a population based cohort of patients with polymyalgia rheumatica. J. Rheumatol. 2005, 32, 65-73.

19. Pulsatelli, L.; Boiardi, L.; Pignotti, E.; Dolzani, P.; Silvestri, T.; Macchioni, P.; Cantini, F.; Salvarani, C.; Facchini, A.; Meliconi, R. Serum interleukin-6 receptor in polymyalgia rheumatica: A potential marker of relapse/recurrence risk. Arthritis. Rheum. 2008, 59, 1147-1154. [CrossRef] [PubMed]

20. Weyand, C.M.; Fulbright, J.W.; Evans, J.M.; Hunder, G.G.; Goronzy, J.J. Corticosteroid requirements in polymyalgia rheumatica. Arch. Intern. Med. 1999, 159, 577-584. [CrossRef] [PubMed]

21. Lee, J.H.; Choi, S.T.; Kim, J.S.; Yoon, B.Y.; Kwok, S.K.; Kim, H.S.; Kim, Y.S.; Song, J.S.; Lee, S.H.; Kim, H.R. Clinical characteristics and prognostic factors for relapse in patients with polymyalgia rheumatica (PMR). Rheumatol. Int. 2013, 33, 1475-1480. [CrossRef]

22. Narvaez, J.; Nolla-Sole, J.M.; Clavaguera, M.T.; Valverde-Garcia, J.; Roig-Escofet, D. Longterm therapy in polymyalgia rheumatica: Effect of coexistent temporal arteritis. J. Rheumatol. 1999, 26, 1945-1952. [PubMed]

23. Schreiber, S.; Buyse, M. The CRP initial response to treatment as prognostic factor in patients with polymyalgia rheumatica. Clin. Rheumatol. 1995, 14, 315-318. [CrossRef] [PubMed]

24. Cantini, F.; Salvarani, C.; Olivieri, I.; Macchioni, L.; Ranzi, A.; Niccoli, L.; Padula, A.; Boiardi, L. Erythrocyte sedimentation rate and $\mathrm{C}$-reactive protein in the evaluation of disease activity and severity in polymyalgia rheumatica: A prospective follow-up study. Semin. Arthritis. Rheum. 2000, 30, 17-24. [CrossRef] [PubMed]

25. Behn, A.R.; Perera, T.; Myles, A.B. Polymyalgia rheumatica and corticosteroids: How much for how long? Ann. Rheum. Dis. 1983, 42, 374-378. [CrossRef]

26. Ayoub, W.T.; Franklin, C.M.; Torretti, D. Polymyalgia rheumatica. Duration of therapy and long-term outcome. Am. J. Med. 1985, 79, 309-315. [CrossRef]

27. Kyle, V.; Hazleman, B.L. The clinical and laboratory course of polymyalgia rheumatica/giant cell arteritis after the first two months of treatment. Ann. Rheum Dis 1993, 52, 847-850. [CrossRef]

28. Cimmino, M.A.; Parodi, M.; Montecucco, C.; Caporali, R. The correct prednisone starting dose in polymyalgia rheumatica is related to body weight but not to disease severity. BMC Musculoskelet. Disord. 2011, $12,94$. [CrossRef] [PubMed]

29. Restuccia, G.; Boiardi, L.; Cavazza, A.; Catanoso, M.; Macchioni, P.; Muratore, F.; Cimino, L.; Aldigeri, R.; Crescentini, F.; Pipitone, N.; et al. Flares in Biopsy-Proven Giant Cell Arteritis in Northern Italy: Characteristics and Predictors in a Long-Term Follow-Up Study. Medicine (Baltimore) 2016, 95, e3524. [CrossRef] [PubMed] 
30. Alba, M.A.; Garcia-Martinez, A.; Prieto-Gonzalez, S.; Tavera-Bahillo, I.; Corbera-Bellalta, M.; Planas-Rigol, E.; Espigol-Frigole, G.; Butjosa, M.; Hernandez-Rodriguez, J.; Cid, M.C. Relapses in patients with giant cell arteritis: Prevalence, characteristics, and associated clinical findings in a longitudinally followed cohort of 106 patients. Medicine (Baltimore) 2014, 93, 194-201. [CrossRef]

31. Farrell, R.J.; Kelleher, D. Glucocorticoid resistance in inflammatory bowel disease. J. Endocrinol. 2003, 178, 339-346. [CrossRef]

32. Van den Akker, E.L.; Koper, J.W.; van Rossum, E.F.; Dekker, M.J.; Russcher, H.; de Jong, F.H.; Uitterlinden, A.G.; Hofman, A.; Pols, H.A.; Witteman, J.C.; et al. Glucocorticoid receptor gene and risk of cardiovascular disease. Arch. Intern. Med. 2008, 168, 33-39. [CrossRef] [PubMed]

33. Manenschijn, L.; van den Akker, E.L.; Lamberts, S.W.; van Rossum, E.F. Clinical features associated with glucocorticoid receptor polymorphisms. An overview. Ann. N. Y. Acad. Sci. 2009, 1179, 179-198. [CrossRef] [PubMed]

34. De Iudicibus, S.; Franca, R.; Martelossi, S.; Ventura, A.; Decorti, G. Molecular mechanism of glucocorticoid resistance in inflammatory bowel disease. World J. Gastroenterol. 2011, 17, 1095-1108. [CrossRef] [PubMed]

35. Buttgereit, F.; Dejaco, C.; Matteson, E.L.; Dasgupta, B. Polymyalgia Rheumatica and Giant Cell Arteritis: A Systematic Review. JAMA 2016, 315, 2442-2458. [CrossRef]

36. Schirmer, M.; Muratore, F.; Salvarani, C. Tocilizumab for the treatment of giant cell arteritis. Expert. Rev. Clin. Immunol. 2018, 14, 339-349. [CrossRef] [PubMed]

37. Quax, R.A.; Manenschijn, L.; Koper, J.W.; Hazes, J.M.; Lamberts, S.W.; van Rossum, E.F.; Feelders, R.A. Glucocorticoid sensitivity in health and disease. Nat. Rev. Endocrinol. 2013, 9, 670-686. [CrossRef] [PubMed]

38. Hernandez-Rodriguez, J.; Segarra, M.; Vilardell, C.; Sanchez, M.; Garcia-Martinez, A.; Esteban, M.J.; Queralt, C.; Grau, J.M.; Urbano-Marquez, A.; Palacin, A.; et al. Tissue production of pro-inflammatory cytokines (IL-1beta, TNFalpha and IL-6) correlates with the intensity of the systemic inflammatory response and with corticosteroid requirements in giant-cell arteritis. Rheumatology (Oxford) 2004, 43, 294-301. [CrossRef] [PubMed]

39. Braun, N.; Fritz, P.; Rieth, A.; Schroth, W.; Kimmel, M.; Biegger, D.; Zakim, D.; Alscher, M.D. Predictors for treatment success and expression of glucocorticoid receptor in giant cell arteritis and polymyalgia rheumatica. J. Rheumatol. 2009, 36, 2269-2276. [CrossRef]

40. Pinero, J.; Bravo, A.; Queralt-Rosinach, N.; Gutierrez-Sacristan, A.; Deu-Pons, J.; Centeno, E.; Garcia-Garcia, J.; Sanz, F.; Furlong, L.I. DisGeNET: A comprehensive platform integrating information on human disease-associated genes and variants. Nucleic. Acids Res. 2017, 45, D833-D839. [CrossRef]

41. Rauzy, O.; Fort, M.; Nourhashemi, F.; Alric, L.; Juchet, H.; Ecoiffier, M.; Abbal, M.; Adoue, D. Relation between HLA DRB1 alleles and corticosteroid resistance in giant cell arteritis. Ann. Rheum. Dis. 1998, 57, 380-382. [CrossRef]

42. Dababneh, A.; Gonzalez-Gay, M.A.; Garcia-Porrua, C.; Hajeer, A.; Thomson, W.; Ollier, W. Giant cell arteritis and polymyalgia rheumatica can be differentiated by distinct patterns of HLA class II association. J. Rheumatol. 1998, 25, 2140-2145.

43. Combe, B.; Sany, J.; Le Quellec, A.; Clot, J.; Eliaou, J.F. Distribution of HLA-DRB1 alleles of patients with polymyalgia rheumatica and giant cell arteritis in a Mediterranean population. J. Rheumatol. 1998, 25, 94-98. [PubMed]

44. Salvarani, C.; Boiardi, L.; Mantovani, V.; Ranzi, A.; Cantini, F.; Olivieri, I.; Viggiani, M.; Bragliani, M.; Macchioni, P. HLA-DRB1, DQA1, and DQB1 alleles associated with giant cell arteritis in northern Italy. J. Rheumatol. 1999, 26, 2395-2399. [PubMed]

45. Martinez-Taboda, V.M.; Bartolome, M.J.; Lopez-Hoyos, M.; Blanco, R.; Mata, C.; Calvo, J.; Corrales, A.; Rodriguez-Valverde, V. HLA-DRB1 allele distribution in polymyalgia rheumatica and giant cell arteritis: Influence on clinical subgroups and prognosis. Semin. Arthritis. Rheum. 2004, 34, 454-464. [CrossRef]

46. Jacobsen, S.; Baslund, B.; Madsen, H.O.; Tvede, N.; Svejgaard, A.; Garred, P. Mannose-binding lectin variant alleles and HLA-DR4 alleles are associated with giant cell arteritis. J. Rheumatol. 2002, 29, 2148-2153.

47. Rodriguez-Rodriguez, L.; Castaneda, S.; Vazquez-Rodriguez, T.R.; Morado, I.C.; Gomez-Vaquero, C.; Mari-Alfonso, B.; Miranda-Filloy, J.A.; Narvaez, J.; Ortego-Centeno, N.; Vicente, E.F.; et al. Role of the rs6822844 gene polymorphism at the IL2-IL21 region in biopsy-proven giant cell arteritis. Clin. Exp. Rheumatol. 2011, 29, S12-S16. 
48. Gonzalez-Gay, M.A.; Oliver, J.; Orozco, G.; Garcia-Porrua, C.; Lopez-Nevot, M.A.; Martin, J. Lack of association of a functional single nucleotide polymorphism of PTPN22, encoding lymphoid protein phosphatase, with susceptibility to biopsy-proven giant cell arteritis. J. Rheumatol. 2005, 32, 1510-1512. [PubMed]

49. Amoli, M.M.; Shelley, E.; Mattey, D.L.; Garcia-Porrua, C.; Thomson, W.; Hajeer, A.H.; Ollier, W.E.; Gonzalez-Gay, M.A. Lack of association between intercellular adhesion molecule-1 gene polymorphisms and giant cell arteritis. J. Rheumatol. 2001, 28, 1600-1604. [PubMed]

50. Martin, J.; Perez-Armengol, C.; Miranda-Filloy, J.A.; Vilchez, J.R.; Lopez-Nevot, M.A.; Garcia-Porrua, C.; Gonzalez-Gay, M.A. Lack of association of a functional -94ins/delATTG NFKB1 promoter polymorphism with susceptibility and clinical expression of biopsy-proven giant cell arteritis in northwest Spain. J. Rheumatol. 2006, 33, 285-288.

51. Salvarani, C.; Casali, B.; Farnetti, E.; Pipitone, N.; Nicoli, D.; Macchioni, P.; Cimino, L.; Bajocchi, G.; Catanoso, M.G.; Boiardi, L. Interleukin-6 promoter polymorphism at position -174 in giant cell arteritis. J. Rheumatol. 2005, 32, 2173-2177. [PubMed]

52. Gonzalez-Gay, M.A.; Hajeer, A.H.; Dababneh, A.; Garcia-Porrua, C.; Mattey, D.L.; Amoli, M.M.; Thomson, W.; Ollier, W.E. IL-6 promoter polymorphism at position -174 modulates the phenotypic expression of polymyalgia rheumatica in biopsy-proven giant cell arteritis. Clin. Exp. Rheumatol. 2002, 20, 179-184. [PubMed]

53. Torres, O.; Palomino-Morales, R.; Vazquez-Rodriguez, T.; Castaneda, S.; Morado, I.C.; Miranda-Filloy, J.A.; Amigo-Diaz, E.; Callejas-Rubio, J.L.; Fernandez-Gutierrez, B.; Martin, J.; et al. Lack of association between IFNGR1 gene polymorphisms and biopsy-proven giant cell arteritis. Clin. Exp. Rheumatol. 2010, 28, 31-34. [PubMed]

54. Gonzalez-Gay, M.A.; Hajeer, A.H.; Dababneh, A.; Garcia-Porrua, C.; Amoli, M.M.; Llorca, J.; Ollier, W.E. Interferon-gamma gene microsatellite polymorphisms in patients with biopsy-proven giant cell arteritis and isolated polymyalgia rheumatica. Clin. Exp. Rheumatol. 2004, 22, S18-S20. [PubMed]

55. Rueda, B.; Lopez-Nevot, M.A.; Lopez-Diaz, M.J.; Garcia-Porrua, C.; Martin, J.; Gonzalez-Gay, M.A. A functional variant of vascular endothelial growth factor is associated with severe ischemic complications in giant cell arteritis. J. Rheumatol. 2005, 32, 1737-1741.

56. Alvarez-Rodriguez, L.; Carrasco-Marin, E.; Lopez-Hoyos, M.; Mata, C.; Fernandez-Prieto, L.; Ruiz-Soto, M.; Calvo, J.; Rodriguez-Valverde, V.; Ruiz, T.; Blanco, R.; et al. Interleukin-1RN gene polymorphisms in elderly patients with rheumatic inflammatory chronic conditions: Association of IL-1RN*2/2 genotype with polymyalgia rheumatica. Hum. Immunol. 2009, 70, 49-54. [CrossRef] [PubMed]

57. Amoli, M.M.; Salway, F.; Zeggini, E.; Ollier, W.E.; Gonzalez-Gay, M.A. MCP-1 gene haplotype association in biopsy proven giant cell arteritis. J. Rheumatol. 2005, 32, 507-510. [PubMed]

58. Rueda, B.; Roibas, B.; Martin, J.; Gonzalez-Gay, M.A. Influence of interleukin 10 promoter polymorphisms in susceptibility to giant cell arteritis in Northwestern Spain. J. Rheumatol. 2007, 34, 1535-1539. [PubMed]

59. Boiardi, L.; Casali, B.; Farnetti, E.; Pipitone, N.; Nicoli, D.; Macchioni, P.; Cimino, L.; Bajocchi, G.; Catanoso, M.G.; Pattacini, L.; et al. Interleukin-10 promoter polymorphisms in giant cell arteritis. Arthritis. Rheum. 2006, 54, 4011-4017. [CrossRef] [PubMed]

60. Rueda, B.; Miranda-Filloy, J.A.; Martin, J.; Gonzalez-Gay, M.A. Association of CD24 gene polymorphisms with susceptibility to biopsy-proven giant cell arteritis. J. Rheumatol. 2008, 35, 850-854.

61. Boiardi, L.; Casali, B.; Farnetti, E.; Pipitone, N.; Nicoli, D.; Macchioni, P.; Cimino, L.; Bajocchi, G.L.; Catanoso, M.G.; Pattacini, L.; et al. Toll-like receptor 4 (TLR4) gene polymorphisms in giant cell arteritis. Clin. Exp. Rheumatol. 2009, 27, S40-S44.

62. Palomino-Morales, R.; Torres, O.; Vazquez-Rodriguez, T.R.; Morado, I.C.; Castaneda, S.; Callejas-Rubio, J.L.; Miranda-Filloy, J.A.; Fernandez-Gutierrez, B.; Martin, J.; Gonzalez-Gay, M.A. Association between toll-like receptor 4 gene polymorphism and biopsy-proven giant cell arteritis. J. Rheumatol. 2009, 36, 1501-1506. [CrossRef] [PubMed]

63. Alvarez-Rodriguez, L.; Lopez-Hoyos, M.; Beares, I.; Munoz Cacho, P.; Mata, C.; Calvo-Alen, J.; Corrales, A.; Tripathi, G.; Blanco, R.; Garcia-Unzueta, M.; et al. Lack of association between Toll-like receptor 4 gene polymorphisms and giant cell arteritis. Rheumatology (Oxford) 2011, 50, 1562-1568. [CrossRef]

64. Alvarez-Rodriguez, L.; Lopez-Hoyos, M.; Beares, I.; Calvo-Alen, J.; Ruiz, T.; Villa, I.; Martinez-Taboada, V.M. Toll-like receptor 9 gene polymorphisms in polymyalgia rheumatica and giant cell arteritis. Scand. J. Rheumatol. 2012, 41, 487-489. [CrossRef] 
65. Salvarani, C.; Casali, B.; Farnetti, E.; Pipitone, N.; Formisano, D.; Nicoli, D.; Macchioni, P.; Cimino, L.; Bajocchi, G.; Grazia Catanoso, M.; et al. PlA1/A2 polymorphism of the platelet glycoprotein receptor IIIA and risk of cranial ischemic complications in giant cell arteritis. Arthritis. Rheum. 2007, 56, 3502-3508. [CrossRef]

66. Salvarani, C.; Boiardi, L.; Mantovani, V.; Ranzi, A.; Cantini, F.; Olivieri, I.; Bragliani, M.; Collina, E.; Macchioni, P. HLA-DRB1 alleles associated with polymyalgia rheumatica in northern Italy: Correlation with disease severity. Ann. Rheum. Dis. 1999, 58, 303-308. [CrossRef]

67. Boiardi, L.; Casali, B.; Farnetti, E.; Pipitone, N.; Nicoli, D.; Cantini, F.; Macchioni, P.; Bajocchi, G.; Catanoso, M.G.; Pulsatelli, L.; et al. Relationship between interleukin 6 promoter polymorphism at position -174, IL-6 serum levels, and the risk of relapse/recurrence in polymyalgia rheumatica. J. Rheumatol. 2006, 33, 703-708.

68. Alvarez-Rodriguez, L.; Lopez-Hoyos, M.; Beares, I.; Mata, C.; Garcia-Unzueta, M.; Calvo-Alen, J.; Blanco, R.; Aurrecoechea, E.; Tripathi, G.; Martinez-Taboada, V.M. Toll-like receptor 4 gene polymorphisms in polymyalgia rheumatica and elderly-onset rheumatoid arthritis. Clin. Exp. Rheumatol. 2011, 29, 795-800. [PubMed]

69. Salvarani, C.; Boiardi, L.; Timms, J.M.; Silvestri, T.; Ranzi, A.; Macchioni, P.L.; Pulsatelli, L.; di Giovine, F.S. Absence of the association with CC chemokine receptor 5 polymorphism in polymyalgia rheumatica. Clin. Exp. Rheumatol. 2000, 18, 591-595. [PubMed]

70. Boiardi, L.; Salvarani, C.; Timms, J.M.; Silvestri, T.; Macchioni, P.L.; di Giovine, F.S. Interleukin-1 cluster and tumor necrosis factor-alpha gene polymorphisms in polymyalgia rheumatica. Clin. Exp. Rheumatol. 2000, 18, 675-681.

71. Amoli, M.M.; Shelley, E.; Mattey, D.L.; Garcia-Porrua, C.; Thomson, W.; Hajeer, A.H.; Ollier, W.E.; Gonzalez-Gay, M.A. Intercellular adhesion molecule-1 gene polymorphisms in isolated polymyalgia rheumatica. J. Rheumatol. 2002, 29, 502-504. [PubMed]

72. Salvarani, C.; Casali, B.; Boiardi, L.; Ranzi, A.; Macchioni, P.; Nicoli, D.; Farnetti, E.; Brini, M.; Portioli, I. Intercellular adhesion molecule 1 gene polymorphisms in polymyalgia rheumatica/giant cell arteritis: Association with disease risk and severity. J. Rheumatol. 2000, 27, 1215-1221.

73. Alvarez-Rodriguez, L.; Carrasco-Marin, E.; Tripathi, G.; Munoz-Cacho, P.; Lopez-Hoyos, M.; Mata, C.; Calvo-Alen, J.; Garcia-Unzueta, M.; Aurrecoechea, E.; Alvarez-Dominguez, C.; et al. Influence of interleukin 10 promoter polymorphisms in polymyalgia rheumatica: Disease susceptibility and functional consequences. Clin. Exp. Rheumatol. 2014, 32, 484-489. [PubMed]

74. Loffers, C.; Heilig, B.; Hecker, M. T-786C single nucleotide polymorphism of the endothelial nitric oxide synthase gene as a risk factor for endothelial dysfunction in polymyalgia rheumatica. Clin. Exp. Rheumatol. 2015, 33, 726-730.

75. Gonzalez-Gay, M.A.; Hajeer, A.H.; Dababneh, A.; Makki, R.; Garcia-Porrua, C.; Thomson, W.; Ollier, W. Seronegative rheumatoid arthritis in elderly and polymyalgia rheumatica have similar patterns of HLA association. J. Rheumatol. 2001, 28, 122-125.

76. Dasgupta, B.; Panayi, G.S. Interleukin-6 in serum of patients with polymyalgia rheumatica and giant cell arteritis. Br. J. Rheumatol. 1990, 29, 456-458. [CrossRef]

77. Samson, M.; Libert, F.; Doranz, B.J.; Rucker, J.; Liesnard, C.; Farber, C.M.; Saragosti, S.; Lapoumeroulie, C.; Cognaux, J.; Forceille, C.; et al. Resistance to HIV-1 infection in caucasian individuals bearing mutant alleles of the CCR-5 chemokine receptor gene. Nature 1996, 382, 722-725. [CrossRef] [PubMed]

78. Cid, M.C.; Hoffman, M.P.; Hernandez-Rodriguez, J.; Segarra, M.; Elkin, M.; Sanchez, M.; Vilardell, C.; Garcia-Martinez, A.; Pla-Campo, M.; Grau, J.M.; et al. Association between increased CCL2 (MCP-1) expression in lesions and persistence of disease activity in giant-cell arteritis. Rheumatology (Oxford) 2006, 45, 1356-1363. [CrossRef]

79. Gonzalez-Gay, M.A.; Hajeer, A.H.; Dababneh, A.; Garcia-Porrua, C.; Amoli, M.M.; Thomson, W.; Ollier, W.E. Corticotropin releasing hormone promoter polymorphisms in giant cell arteritis and polymyalgia rheumatica. Clin. Exp. Rheumatol. 2002, 20, 133-138. [PubMed]

80. Serrano, A.; Marquez, A.; Mackie, S.L.; Carmona, F.D.; Solans, R.; Miranda-Filloy, J.A.; Hernandez-Rodriguez, J.; Cid, M.C.; Castaneda, S.; Morado, I.C.; et al. Identification of the PTPN22 functional variant R620W as susceptibility genetic factor for giant cell arteritis. Ann. Rheum. Dis. 2013, 72, 1882-1886. [CrossRef] 
81. Meliconi, R.; Pulsatelli, L.; Dolzani, P.; Boiardi, L.; Macchioni, P.; Salvarani, C.; Silvestri, T.; Frizziero, L.; Facchini, A. Vascular endothelial growth factor production in polymyalgia rheumatica. Arthritis. Rheum. 2000, 43, 2472-2480. [CrossRef]

82. Boiardi, L.; Casali, B.; Nicoli, D.; Farnetti, E.; Chen, Q.; Macchioni, P.; Catanoso, M.G.; Pulsatelli, L.; Meliconi, R.; Salvarani, C. Vascular endothelial growth factor gene polymorphisms in giant cell arteritis. J. Rheumatol. 2003, 30, 2160-2164.

83. Carmona, F.D.; Martin, J.; Gonzalez-Gay, M.A. New insights into the pathogenesis of giant cell arteritis and hopes for the clinic. Expert Rev. Clin. Immunol. 2016, 12, 57-66. [CrossRef]

84. Marquez, A.; Hernandez-Rodriguez, J.; Cid, M.C.; Solans, R.; Castaneda, S.; Fernandez-Contreras, M.E.; Ramentol, M.; Morado, I.C.; Narvaez, J.; Gomez-Vaquero, C.; et al. Influence of the IL17A locus in giant cell arteritis susceptibility. Ann. Rheum. Dis. 2014, 73, 1742-1745. [CrossRef]

85. Deng, J.; Younge, B.R.; Olshen, R.A.; Goronzy, J.J.; Weyand, C.M. Th17 and Th1 T-cell responses in giant cell arteritis. Circulation 2010, 121, 906-915. [CrossRef]

86. Espigol-Frigole, G.; Corbera-Bellalta, M.; Planas-Rigol, E.; Lozano, E.; Segarra, M.; Garcia-Martinez, A.; Prieto-Gonzalez, S.; Hernandez-Rodriguez, J.; Grau, J.M.; Rahman, M.U.; et al. Increased IL-17A expression in temporal artery lesions is a predictor of sustained response to glucocorticoid treatment in patients with giant-cell arteritis. Ann. Rheum. Dis. 2013, 72, 1481-1487. [CrossRef]

87. Weyand, C.M.; Goronzy, J.J. Immune mechanisms in medium and large-vessel vasculitis. Nat. Rev. Rheumatol. 2013, 9, 731-740. [CrossRef] [PubMed]

88. Ciccia, F.; Rizzo, A.; Guggino, G.; Cavazza, A.; Alessandro, R.; Maugeri, R.; Cannizzaro, A.; Boiardi, L.; Iacopino, D.G.; Salvarani, C.; et al. Difference in the expression of IL-9 and IL-17 correlates with different histological pattern of vascular wall injury in giant cell arteritis. Rheumatology (Oxford) 2015, 54, 1596-1604. [CrossRef] [PubMed]

89. Carmona, F.D.; Serrano, A.; Rodriguez-Rodriguez, L.; Castaneda, S.; Miranda-Filloy, J.A.; Morado, I.C.; Narvaez, J.; Solans, R.; Sopena, B.; Mari-Alfonso, B.; et al. A nonsynonymous functional variant of the ITGAM gene is not involved in biopsy-proven giant cell arteritis. J. Rheumatol. 2011, 38, 2598-2601. [CrossRef] [PubMed]

90. Palomino-Morales, R.; Vazquez-Rodriguez, T.R.; Morado, I.C.; Castaneda, S.; Ortego-Centeno, N.; Miranda-Filloy, J.A.; Lamas, J.R.; Martin, J.; Gonzalez-Gay, M.A. Lack of association between STAT4 gene polymorphism and biopsy-proven giant cell arteritis. J. Rheumatol. 2009, 36, 1021-1025. [CrossRef]

91. Rodriguez-Rodriguez, L.; Castaneda, S.; Vazquez-Rodriguez, T.R.; Morado, I.C.; Mari-Alfonso, B.; Gomez-Vaquero, C.; Miranda-Filloy, J.A.; Ortego-Centeno, N.; Narvaez, J.; Blanco, R.; et al. Influence of IL2RA rs2104286 polymorphism in the risk of biopsy-proven giant cell arteritis. J. Rheumatol. 2010, 37, 2331-2333. [CrossRef]

92. Palomino-Morales, R.; Torres, O.; Vazquez-Rodriguez, T.R.; Castaneda, S.; Morado, I.C.; Miranda-Filloy, J.A.; Amigo-Diaz, E.; Callejas-Rubio, J.L.; Fernandez-Gutierrez, B.; Martin, J.; et al. Lack of association between the rs6920220 (G/A) polymorphism of the 6q23 region and biopsy-proven giant cell arteritis. J. Rheumatol. 2010, 37, 1020-1023. [CrossRef]

93. Torres, O.; Palomino-Morales, R.; Vazquez-Rodriguez, T.R.; Castaneda, S.; Morado, I.C.; Miranda-Filloy, J.A.; Ortego-Centeno, N.; Gonzalez-Alvaro, I.; Fernandez-Gutierrez, B.; Martin, J.; et al. Lack of association between TRAF1/C5 gene polymorphisms and biopsy-proven giant cell arteritis. J. Rheumatol. 2010, 37, 131-135. [CrossRef] [PubMed]

94. Carmona, F.D.; Serrano, A.; Rodriguez-Rodriguez, L.; Callejas, J.L.; Simeon, C.P.; Carreira, P.; Castaneda, S.; Solans, R.; Blanco, R.; Spanish Scleroderma, G.; et al. Evaluation of a shared autoimmune disease-associated polymorphism of TRAF6 in systemic sclerosis and giant cell arteritis. J. Rheumatol. 2012, 39, 1275-1279. [CrossRef]

95. Rodriguez-Rodriguez, L.; Carmona, F.D.; Castaneda, S.; Miranda-Filloy, J.A.; Morado, I.C.; Narvaez, J.; Mari-Alfonso, B.; Gomez-Vaquero, C.; Amigo-Diaz, E.; Rios-Fernandez, R.; et al. Role of rs1343151 IL23R and rs3790567 IL12RB2 polymorphisms in biopsy-proven giant cell arteritis. J. Rheumatol. 2011, 38, 889-892. [CrossRef] [PubMed] 
96. Serrano, A.; Carmona, F.D.; Miranda-Filloy, J.A.; Castaneda, S.; Rodriguez-Rodriguez, L.; Morado, I.C.; Gomez-Vaquero, C.; Solans, R.; Sopena, B.; Blanco, R.; et al. Autoimmune disease-associated CD226 gene variants are not involved in giant cell arteritis susceptibility in the Spanish population. Clin. Exp. Rheumatol. 2012, 30, S29-S33. [PubMed]

97. Salvarani, C.; Casali, B.; Farnetti, E.; Pipitone, N.; Nicoli, D.; Macchioni, P.L.; Cimino, L.; Bajocchi, G.L.; Catanoso, M.G.; Pattacini, L.; et al. -463 G/A myeloperoxidase promoter polymorphism in giant cell arteritis. Ann. Rheum. Dis. 2008, 67, 485-488. [CrossRef] [PubMed]

98. Palomino-Morales, R.; Vazquez-Rodriguez, T.R.; Miranda-Filloy, J.A.; Martin, J.; Gonzalez-Gay, M.A. C-reactive protein gene polymorphisms in biopsy-proven giant cell arteritis from Northwestern Spain. J. Rheumatol. 2009, 36, 341-346. [CrossRef]

99. Serrano, A.; Carmona, F.D.; Castaneda, S.; Miranda-Filloy, J.A.; Morado, I.C.; Gomez-Vaquero, C.; Solans, R.; Sopena, B.; Blanco, R.; Unzurrunzaga, A.; et al. A case-control study suggests that the CCR6 locus is not involved in the susceptibility to giant cell arteritis. Clin. Exp. Rheumatol. 2013, 31, S5-S8.

100. Torres, O.; Palomino-Morales, R.; Vazquez-Rodriguez, T.R.; Castaneda, S.; Morado, I.C.; Miranda-Filloy, J.A.; Valero, F.; Callejas-Rubio, J.L.; Fernandez-Gutierrez, B.; Martin, J.; et al. Lack of association between IRF5 gene polymorphisms and biopsy-proven giant cell arteritis. J. Rheumatol. 2010, 37, 136-140. [CrossRef]

101. Torres, O.; Palomino-Morales, R.; Castaneda, S.; Vazquez-Rodriguez, T.R.; Morado, I.C.; Miranda-Filloy, J.A.; Amigo-Diaz, E.; Vicente, E.F.; Ortego-Centeno, N.; Fernandez-Gutierrez, B.; et al. Role of BANK1 gene polymorphisms in biopsy-proven giant cell arteritis. J. Rheumatol. 2010, 37, 1502-1504. [CrossRef]

102. Salvarani, C.; Casali, B.; Nicoli, D.; Farnetti, E.; Macchioni, P.; Catanoso, M.G.; Chen, Q.; Bajocchi, G.; Boiardi, L. Endothelial nitric oxide synthase gene polymorphisms in giant cell arteritis. Arthritis. Rheum. 2003, 48, 3219-3223. [CrossRef] [PubMed]

103. Rodriguez-Rodriguez, L.; Castaneda, S.; Vazquez-Rodriguez, T.R.; Morado, I.C.; Mari-Alfonso, B.; Gomez-Vaquero, C.; Miranda-Filloy, J.A.; Narvaez, J.; Ortego-Centeno, N.; Blanco, R.; et al. Influence of CD40 rs1883832 polymorphism in susceptibility to and clinical manifestations of biopsy-proven giant cell arteritis. J. Rheumatol. 2010, 37, 2076-2080. [CrossRef]

104. Torres, O.; Palomino-Morales, R.; Vazquez-Rodriguez, T.R.; Castaneda, S.; Morado, I.C.; Miranda-Filloy, J.A.; Ortego-Centeno, N.; Fernandez-Gutierrez, B.; Martin, J.; Gonzalez-Gay, M.A. Role of the C8orf13-BLK region in biopsy-proven giant cell arteritis. Hum. Immunol. 2010, 71, 525-529. [CrossRef]

105. Karbach, S.; Croxford, A.L.; Oelze, M.; Schuler, R.; Minwegen, D.; Wegner, J.; Koukes, L.; Yogev, N.; Nikolaev, A.; Reissig, S.; et al. Interleukin 17 drives vascular inflammation, endothelial dysfunction, and arterial hypertension in psoriasis-like skin disease. Arterioscler. Thromb. Vasc. Biol. 2014, 34, 2658-2668. [CrossRef] [PubMed]

106. Zhang, H.; Watanabe, R.; Berry, G.J.; Vaglio, A.; Liao, Y.J.; Warrington, K.J.; Goronzy, J.J.; Weyand, C.M. Immunoinhibitory checkpoint deficiency in medium and large vessel vasculitis. Proc. Natl. Acad. Sci. USA 2017, 114, E970-E979. [CrossRef]

107. Saadoun, D.; Garrido, M.; Comarmond, C.; Desbois, A.C.; Domont, F.; Savey, L.; Terrier, B.; Geri, G.; Rosenzwajg, M.; Klatzmann, D.; et al. Th1 and Th17 cytokines drive inflammation in Takayasu arteritis. Arthritis. Rheumatol. 2015, 67, 1353-1360. [CrossRef]

(C) 2019 by the authors. Licensee MDPI, Basel, Switzerland. This article is an open access article distributed under the terms and conditions of the Creative Commons Attribution (CC BY) license (http://creativecommons.org/licenses/by/4.0/). 